OPEN ACCESS

Edited by:

Raymond Chuen-Chung Chang,

University of Hong Kong,

Hong Kong

Reviewed by:

Varun Kesherwani,

University of Nebraska

Medical Center, USA

Abby Manthey,

University of Hong Kong,

Hong Kong

*Correspondence:

Slavica Krantic

slavica.krantic@crc.jussieu.fr

Specialty section:

This article was submitted to Neurodegeneration,

a section of the journal

Frontiers in Neurology

Received: 03 May 2016

Accepted: 27 July 2016

Published: 08 August 2016

Citation:

Masuzzo A, Dinet V, Cavanagh C,

Mascarelli $F$ and Krantic $S$

(2016) Amyloidosis in Retinal

Neurodegenerative Diseases.

Front. Neurol. 7:127.

doi: 10.3389/fneur.2016.00127

\section{Amyloidosis in Retinal Neurodegenerative Diseases}

\author{
Ambra Masuzzo', Virginie Dinet ${ }^{1}$, Chelsea Cavanagh ${ }^{2}$, Frederic Mascarelli' \\ and Slavica Krantic ${ }^{\text {* }}$
}

${ }^{1}$ Centre de Recherche des Cordeliers, Institut national de la santé et de la recherche médicale (INSERM), Université Paris Descartes, Sorbonne Paris Cité, UMR_S 1138, Université Pierre et Marie Curie Université Paris 06, Sorbonne Universités, Paris, France, ${ }^{2}$ Department of Neuroscience, Douglas Hospital Research Center, Montreal, QC, Canada

As a part of the central nervous system, the retina may reflect both physiological processes and abnormalities related to pathologies that affect the brain. Amyloidosis due to the accumulation of amyloid-beta $(A \beta)$ was initially regarded as a specific and exclusive characteristic of neurodegenerative alterations seen in the brain of Alzheimer's disease (AD) patients. More recently, it was discovered that amyloidosis-related alterations, similar to those seen in the brain of Alzheimer's patients, also occur in the retina. Remarkably, these alterations were identified not only in primary retinal pathologies, such as age-related macular degeneration (AMD) and glaucoma, but also in the retinas of Alzheimer's patients. In this review, we first briefly discuss the biogenesis of $A \beta, a$ peptide involved in amyloidosis. We then discuss some pathological aspects (synaptic dysfunction, mitochondrial failure, glial activation, and vascular abnormalities) related to the neurotoxic effects of $A \beta$. We finally highlight common features shared by $A D, A M D$, and glaucoma in the context of $A \beta$ amyloidosis and further discuss why the retina, due to the transparency of the eye, can be considered as a "window" to the brain.

\footnotetext{
Keywords: Alzheimer's disease, age-related macular degeneration, glaucoma, neurodegeneration, synaptic and mitochondrial dysfunction, micoangiopathy, neuroinflammation
}

\section{INTRODUCTION}

Pathological alterations, such as synaptic dysfunctions, neuronal cell loss, inflammatory responses, microvasculature abnormalities, mitochondrial failure, and oxidative stress, have been associated with amyloid-beta $(A \beta)$ in the brain. However, similar pathological alterations have more recently also been reported in the retina where they may mirror analogous events occurring in the brain (1). The present review will focus on these aforementioned aspects of $A \beta$ 's deleterious effects but does not have the ambition to cover all aspects of $A \beta$ cytotoxicity. For instance, the issues related to aberrant $A \beta$ clearance will not be discussed here since they have been recently extensively reviewed elsewhere [e.g., Ref. (2)].

Retinal accumulation of $A \beta$ is broadly recognized as being involved in amyloidosis-associated neurodegeneration. Pathological hallmarks of amyloidosis are related to the accumulation of specific types of proteins, including $A \beta$, prone to oligomerize with a high content of beta $(\beta)$-sheet structures (3). Among the neurodegenerative diseases related to $A \beta$ amyloidosis, Alzheimer's disease (AD) is certainly the best known and the most studied. More recently, it has been recognized that $\mathrm{A} \beta$-related amyloidosis also occurs during glaucoma and age-related macular degeneration (AMD). Historically and up to very recently, $\mathrm{AD}$ was considered as an exclusively cerebral disorder, while glaucoma and AMD were regarded as neurodegenerative disorders specific to the retina. However, 
it is increasingly clear that AD-like pathological alterations seen in the brain also occur in the retina (4), where they may even start earlier. Conversely, the pathological phenomena observed in glaucoma, for example, are associated with neurodegeneration of selected brain areas (5). Altogether, this new evidence suggests that the retina may be used as the "window" to the brain for the study of the earliest pathophysiological changes involved in neurodegeneration. This attractive idea is behind different aspects of amyloidosis that will be discussed here.

Parkinson's disease (PD), which shares many features of A $\beta$ amyloidosis with $\mathrm{AD}$, glaucoma, and $\mathrm{AMD}$, will not be discussed here, and we recommend a number of excellent and exhaustive reviews on this topic $(6,7)$. Indeed, although $\mathrm{PD}$ is considered an amyloidosis-associated disease, involving the accumulation of both $\mathrm{A} \beta$ and $\alpha$-synuclein, the relevant fibrils have not been identified in the $\mathrm{PD}$ retina (8). This is in sharp contrast with the presence of $\mathrm{A} \beta$ plaques, identical to those found in $\mathrm{AD}$-vulnerable brain areas that have been identified in the retina $(9,10)$. Furthermore, $\mathrm{A} \beta$-amyloidosis seen in PD is sometimes considered as an epiphenomenon to the oligomerization of $\alpha$-synuclein into structures known as Lewy bodies. Consequently, rigorous analysis of alterations specific to $\mathrm{A} \beta$-amyloidosis in $\mathrm{PD}$ would require a systematic comparative follow-up of cohorts composed of "mixed" $\mathrm{PD}$ (displaying both $\alpha$-synuclein and A $\beta$-amyloidosis) and "pure" PD (displaying exclusively $\alpha$-synuclein amyloidosis). Such studies, similar to the one reported by Bertrand and colleagues (11), are still relatively scarce. Finally, there is no consensus about the precise type of pathological alterations in the $\mathrm{PD}$ retina, since thickening (12), thinning (13), and absence of change (14) in the retinal nerve fiber layer (RNFL) have all been reported. The analysis of retinal $\mathrm{A} \beta$-amyloidosis in $\mathrm{PD}$ would therefore be more complicated. By consequence, this review will focus only on $\mathrm{AD}$, glaucoma, and AMD.

\section{BIOLOGY OF AMYLOID- $\beta$ AND ITS PRECURSOR APP}

Amyloid precursor protein (APP), a type 1 transmembrane glycoprotein, belongs to a family of proteins, which in mammals include APP-like protein-1 (APLP1) and APP-like protein-2 (APLP2) (15). Despite the widespread expression of the APP gene in mammalian and non-mammalian cells, the physiological role of APP is still unclear. APP-related mRNA has been found not only in the nervous system but also in the immune system, muscles, and other organs, such as the pancreas, lung, and kidney $(16,17)$. Alternative splicing of APP mRNA gives rise to multiple isoforms, which are differentially expressed among various tissues and different stages of development. In particular, APP is upregulated during brain development, and specific APP variants are associated with neurite outgrowth and synaptogenesis $(18,19)$.

There are three major APP isoforms, APP770, APP751, and APP695, which are all generated from the alternative splicing of exons 7 and/or 8. APP695 is mainly neuronal, whereas the other two variants are principally non-neuronal (20). APP polypeptides undergo posttranslational modifications (such as glycosylation and phosphorylation) and are subsequently addressed to the plasma membrane via the constitutive secretory pathway
(Figure 1A). Successively, APP is internalized through clathrinmediated endocytosis and reaches the endosomal system. Part of endosomal APP is recycled to the cell surface, whereas another conspicuous part is degraded in lysosomes $(21,22)$. In the steady state, APP is preferentially localized in the Golgi and in the transGolgi network, and only a tiny fraction is localized on the cell surface.

Amyloid precursor protein can be posttranslationally processed through two distinct pathways [reviewed in Ref. (23)] (Figure 1B). The amyloidogenic pathway involves sequential cleavage steps by $\beta$-secretase and $\gamma$-secretase, which generates $A \beta$. The second pathway, which is predominant, involves sequential cleavage steps by $\alpha$-secretase and $\gamma$-secretase but does not yield $A \beta$. Indeed, $\alpha$-secretase cleavage occurs within the $A \beta$ peptide region, preventing $A \beta$ formation. It has been shown that proteases belonging to the A-disintegrin and metalloproteinase (ADAM) family have $\alpha$-secretase activity (24-26). Since ADAMs are cell surface proteins, $\alpha$-secretase cleavage likely occurs at the level of the plasma membrane and involves the membrane pool of APP (27). $\alpha$-secretase cleavage leads to the formation of an amino-terminal fragment called secreted APP (sAPP) $\alpha$ and a carboxy-terminal fragment called CTF83. $\beta$-secretase is a type 1 transmembrane protease, and its cleavage leads to the formation of sAPP $\beta$ and CTF99. In converse to $\alpha$-secretase cleavage, $\beta$-secretase cleavage occurs mainly in endocytic vesicles and not at the cell surface, where both $\beta$-site APP cleaving enzyme-1 (BACE1) and APP are swiftly recycled. The first cleavage step is followed by $\gamma$-secretase cleavage in both pathways. The latter is a protein complex composed of at least four proteins: presenilin (PS) 1 or 2, nicastrin, presenilin enhancer 2 (Pen 2), and anterior pharynx defective 1 (Aph-1) (28). $\gamma$-secretase processes CTF83 and CTF99, yielding the APP intracellular domain (AICD) plus the fragment $\mathrm{p} 3$ and AICD plus $A \beta$, respectively. $A \beta$ peptides of different lengths, from 38 to 43 amino acids, can be generated by $\gamma$-secretase cleavage; however, $A \beta 1-42$ and $A \beta 1-40$ are considered to be the most relevant forms to amyloidosis.

Since APP undergoes sequential cleavage steps, it has been difficult to distinguish the physiological role of APP from those of its cleavage products. Generally, the role of APP in the brain is regarded as beneficial and often associated with its cleavage product, sAPP $\alpha$. It has been shown that APP promotes cell proliferation, neuronal stem cell differentiation, neurite outgrowth, synaptogenesis, cell adhesion, and regulates long-term potentiation (LTP). APP-KO mice are viable and fertile, suggesting that APP - or its products - are not essential for development or alternatively, are part of a network of proteins with redundant functions (29). However, APP-deficient mice present various abnormalities, such as reduced body and brain size, hypersensitivity to seizures, and impaired learning and LTP. These phenotypes are rescued by the introduction of $\mathrm{sAPP} \alpha$ in APP-deficient mice, suggesting that sAPP $\alpha$ may play an important role in brain development and function (30).

Compared with $\operatorname{sAPP} \alpha$, little is known about the putative physiological roles of other cleavage products from the nonamyloidogenic and amyloidogenic pathways. However, it has been proposed that $A \beta$ may regulate synaptic activity, although controversial results have been reported on its beneficial versus 


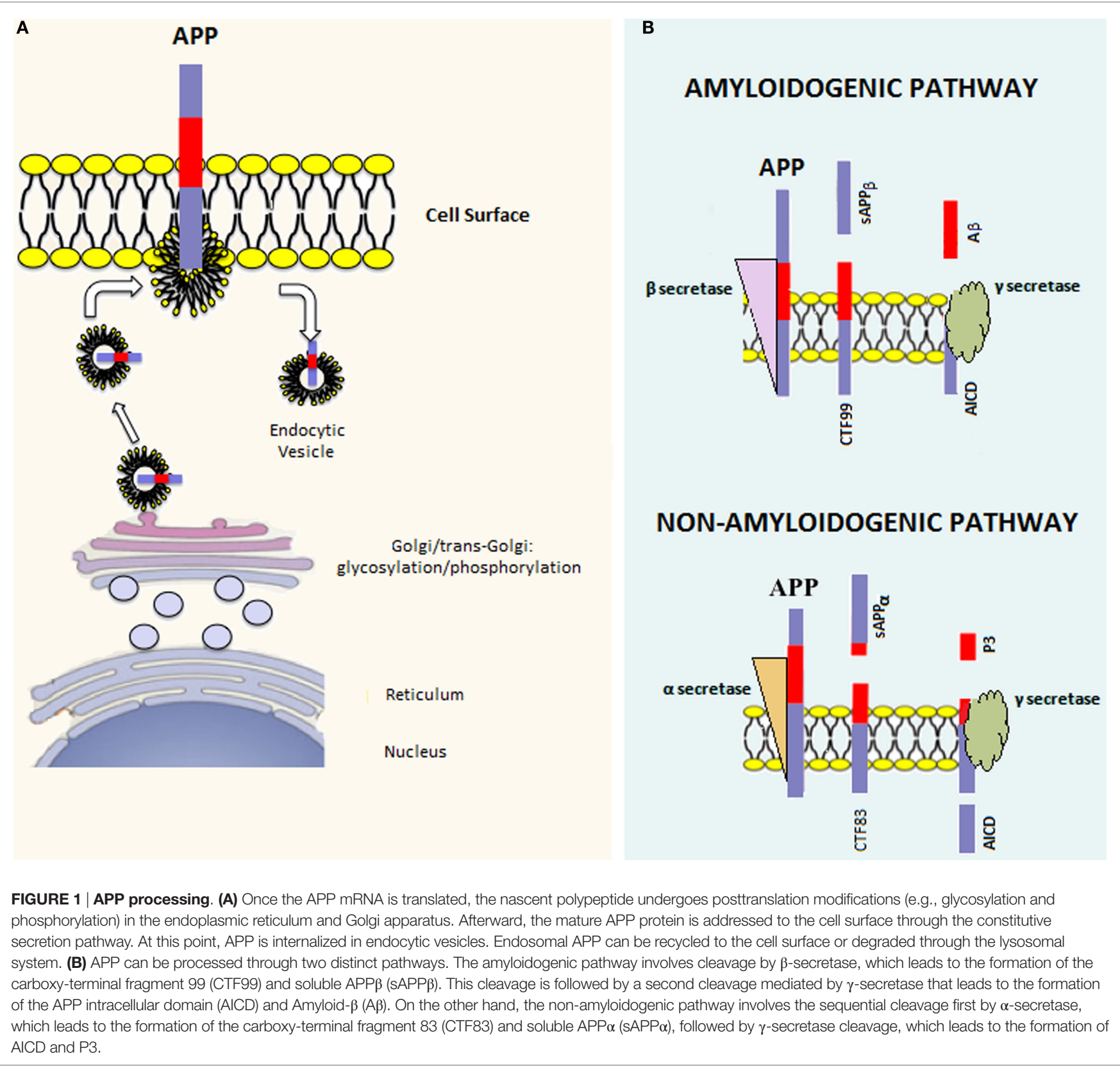

deleterious effects $(31,32)$. In addition, $A \beta$ may be involved in the control of cholesterol transport (33) and lipid homeostasis (34). For instance, direct activation of sphingomyelinase and inhibition of hydroxymethylglutaryl-CoA reductase (HMGR) by $A \beta 1-42$ and $A \beta 1-40$ have been demonstrated (35). The question of the physiological role of $A \beta$ remains open, and further studies are clearly needed in this field.

\section{AMYLOID- $\beta$ AND ITS PRECURSOR IN THE EYE AND RETINA}

The retina is a highly specialized neurosensory tissue, which lines the back of the eye. It is an integral part of the brain comprising six different types of neuronal cells and two types of macroglia cells: retinal Müller glial cells and astrocytes. Retinal and central nervous system (CNS) neurons are derived from common progenitors (36). Differentiated retinal neurons are organized into a well-defined laminar structure and are distributed into three cell and two synaptic layers. The outer segment of the retina is populated by two different types of photoreceptors: cones and rods, which are able to detect light and form the outer nuclear layer (ONL). The detected light signal is transmitted to the cells located at the inner nuclear layer (INL), mainly the bipolar cells followed by retinal ganglion cells (RGCs), either directly or indirectly via type II amacrine cells. The latter, together with horizontal cells, modulate glutamatergic neurotransmission along the main synaptic axis comprising photoreceptors, bipolar, and ganglion cells. The principal function of the INL cells is to integrate and regulate 
the signal input. The RGC axons converge into the optic nerve fibers, which convey the signal to the visual cortex (37).

To date, the physiological roles of APP in the retina have not been extensively investigated, although a consensus has been met about its expression by retinal pigmented epithelial (RPE) cells in the healthy retina (38). The role of APP in the development of the mouse retina has been recognized such that APP is required for the full differentiation of the AII subtype of amacrine cells. Similar to its role in the brain, APP may be implicated in retinal synaptogenesis. Indeed, APP participates in the developmental determination of the inner plexiform layer (IPL), where amacrine cells synapse to bipolar and ganglion cells (39). Concerning the physiological role of APP in adult mice, it has been shown that APP regulates inner retinal layer function. Indeed, APP-KO mice display alterations in the rod and cone pathways. However, these mice do not present any major deficits in visual function; therefore, APP is not likely a required factor (40). Among all retinal neurons, at least in the rabbit, ganglion cells are the sole cells able to synthesize and express APP on their plasma membrane in the absence of any pathological insult (41). In the human retina, APP expression is age-dependent and was revealed in RGC neurons and the RNFL (42).

Concerning $A \beta$, there is no published data on its putative physiological role in the retina. Of interest, the expression of BACE1 has been recently reported in the blood-brain barrier endothelial cells of mouse, bovine, and human origin, thus suggesting putative local production of $A \beta$ in cerebral blood vessels (43). It remains unknown whether retinal vessel endothelial cells display analogous BACE1 expression. By contrast, BACE1 expression has been reported in the plexiform layer of the rat retina pointing to its synaptic localization (44).

The other parts of the eye have been much less studied in terms of the expression and function of APP and its cleavage products. However, both APP and the proteolytic enzymes involved in its cleavage were found to be expressed in some other eye compartments. For instance, APP and the secretases involved in its processing were identified in the lens (45). Similarly, A $\beta$ was identified both in the lens (46) and in the vitreous fluid (47).

\section{PATHOLOGICAL ACCUMULATION OF AMYLOID- $\beta$ : AMYLOIDOSIS, AMYLOIDOPATHY, AND AMYLOIDOGENESIS}

Different terms have been associated with the pathological accumulation of $\mathrm{A} \beta$, with amyloidosis historically being used first. Amyloidosis is a broad term designating a metabolic disease characterized by the extracellular accumulation of globular or natively unfolded or misfolded amyloidogenic polypeptides. Amyloidogenic polypeptides contain a high proportion of $\beta$-sheets and have a great propensity to aggregate into highly organized and kinetically stable amyloid fibrils, amorphous aggregates, or oligomers. To date, more than 20 precursor proteins of fibrils (including APP) have been identified in systemic and localized amyloidosis (3). A remarkable property of these fibrils is that, independent of the type of the precursor protein, they are all $80-100 \AA$ in width. Furthermore, these fibrils organize in a tridimensional $\beta$-pleated sheet conformation with the direction of the polypeptide backbone perpendicular to the fibril axis (cross-beta structure). Another remarkable characteristic of amyloidogenic peptides and derived aggregates is their affinity for the Congo red stain (48). The A $\beta$-related amyloidopathies consist of increased intra- and/ or extracellular accumulation of $A \beta$ and deposition of $A \beta$ in the form of insoluble material, such as amyloid plaques or drusens. Several disorders are associated with amyloidopathies, and most of them are neurodegenerative diseases (e.g., AD, PD, polyglutamine diseases, prion disorders, and AMD).

Amyloid-beta is produced via the amyloidogenic pathway of APP processing. However, the mechanisms by which this pathway may take over the non-amyloidogenic pathway are poorly understood, especially considering that both pathways coexist in physiological conditions (49). Many genetic and epigenetic factors may be involved, but the evidence points to an increase in the ratio of $\beta$ - over $\alpha$-secretase activity as a trigger. This change in the subtle balance between secretase activities in physiological conditions might be associated with the positive control of $\beta$-secretase activity by its substrate APP and directly related to APP overexpression and subsequent increase in $A \beta$ production (50). Over the course of normal aging, $A \beta$ is deposited subretinally in the mouse and human retina (51). With age, $A \beta$ accumulates at the interface of the RPE and the photoreceptor outer segment tips. This finding is consistent with increased A $\beta 1-42$ secretion by aged human RPE cells (52). As $\mathrm{A} \beta$ accumulates subretinally, microglial cells in normal aged mice become bloated with cellular debris and $A \beta$ (51). The accumulation of $A \beta$ in the subretinal space might contribute to the $23-30 \%$ reduction in photoreceptors that occurs over human lifetimes (53).

\section{AMYLOID- $\beta$ AGGREGATION AND TOXICITY}

An increase in $\mathrm{A} \beta$ production above normal physiological levels yields cytotoxicity. Among most common $A \beta$ species (i.e., 1-40 and 1-42 amino acid-containing isoforms), $A \beta 1-42$ is considered the most neurotoxic as it is more prone to oligomerization (54). The amyloid aggregation pathway is still poorly understood and several intermediates are likely involved. Small soluble A $\beta$ monomers can interact to form $A \beta$ oligomers in the extracellular space. $A \beta$ oligomers aggregate to form larger fibrils, which in turn aggregate to form extracellular plaques. The mechanisms of $A \beta$ toxicity are still unclear, and different hypotheses have been proposed. According to the original "amyloid- $\beta$ cascade hypothesis," insoluble amyloid fibrils are the main molecular culprit underlying toxicity (55). More recently, this hypothesis has been revised to the "oligomeric amyloid- $\beta$ hypothesis" (56). It is currently believed that the most toxic intermediates are small oligomers (with degree of polymerization lower than 10), also known as amyloid- $\beta$ diffusible ligands (ADDL) or protofibrils. The latter have a bigger diffusivity and a larger surface-to-volume ratio that leads to the exposure of hydrophobic patches (57). However, it is not yet clear which oligomeric species is "the most" toxic 
since dimers/trimers (58), tetramers (59), and duodecamers such as $A \beta^{\star} 56$ (60) have all been considered as plausible candidates depending on the paradigm (in vivo, in vitro) or species (murine, human) studied.

Soluble A $\beta$ oligomers, although they are certainly not involved in all the aspects of $\mathrm{AD}$, are still regarded as key initial triggers of pathogenesis (61). The bioactive pool of soluble $A \beta$ comprises two fractions: the first is generated in the endosomal compartment and secreted into the extracellular space by exocytosis and the second is intracellular and has been found in both $\mathrm{AD}$ patients and animal models of the disease $(62,63)$. Cellular mechanisms by which soluble oligomers exert neurotoxic effects are multifaceted, involving synaptotoxicity and mitochondrial dysfunction likely related to oxidative stress and metabolic impairment. Insoluble $A \beta$ aggregates also contribute to $A \beta$ toxicity either directly through the release of soluble oligomers (64) or indirectly via adaptive cellular responses, such as glial and endothelial activation, which can yield neuroinflammation (65) and $\mathrm{A} \beta$-related angiopathy (66), respectively.

\section{Amyloid- $\beta$ and Synaptic Dysfunction}

One of the prominent facets of $A \beta$ toxicity concerns synaptic loss (67). This toxicity may be related to a deviation from the $\mathrm{A} \beta$-associated modulation of synaptic excitability under physiological conditions (31). Indeed, increased synaptic activity may enhance $A \beta$ release at the synaptic level, reducing excitatory postsynaptic transmission. In particular, it has been shown both in vitro and in vivo, that $\mathrm{A} \beta$ oligomers reduce glutamatergic synaptic transmission by decreasing the number of $\alpha$-amino3-hydroxy-5-methyl-4-isoxazolepropionic acid (AMPA) and $N$-methyl D-aspartate (NMDA) receptors at the synapse (68-71) (Figure 2A). A decrease in AMPA receptors by A $\beta$ has been related to increased phosphorylation of the $\mathrm{Ca}^{2+}$-permeable subunit, GluR2, and a subsequent increase of intracellular $\mathrm{Ca}^{2+}$ levels (72). A decrease in NMDA receptors by $A \beta$ involves a similar mechanism via dephosphorylation of the NR2B subunit and subsequent increase in receptor endocytosis (73). Thus, A $\beta$ is part of a refined regulatory circuit in which intermediate levels of $A \beta$ are correlated with a physiological increase in presynaptic activity, whereas lower or higher $\mathrm{A} \beta$ levels are correlated with reduced presynaptic and postsynaptic transmission, respectively (74). Likely, A $\beta$ differentially affects synaptic activity, depending on synapse type, neuron type, and/or brain region, leading to the imbalance and instability of neuronal networks (75). At the cellular level, $\mathrm{A} \beta$-mediated alterations involve a shift toward increased excitability manifesting in a decreased resting potential of the neuronal membrane (76). Similarly, the addition of exogenous $\mathrm{A} \beta$ oligomers to hippocampal neurons induced hyperpolarization of the action potential (AP) threshold and decreased afterhyperpolarization (AHP), both compatible with an increase in neuronal excitability (77).

Of note, the vast majority of the above-discussed data has been obtained in vitro, by treating cerebral (hippocampal or cortical primary) neurons with soluble $A \beta$ oligomers. Analogous data for retinal neurons are scarce, although it has been reported that intravitreal injection of $A \beta$ triggers acute photoreceptor cell death and delayed RGC apoptosis (78). The latter likely involves an indirect mechanism via the activation of Müller cells (78). Finally, a similar $\mathrm{A} \beta$ challenge by intravitreal injection resulted in an impaired pattern of acetylcholine, $\boldsymbol{\gamma}$-aminobutyric acid (GABA), and serotonin neurotransmitter expression with catecholaminergic markers being relatively unaffected (79).

\section{Amyloid- $\beta$ and Mitochondrial Dysfunction}

Mitochondrial dysfunction is a common feature of various neurodegenerative diseases and causes alterations in mitochondrial respiratory enzyme complex activities, oxidative stress, opening of mitochondrial permeability transition pores (mPTPs), and enhanced apoptosis (80). In the brain, intracellular $\mathrm{A} \beta$ has been associated with axonopathy and apoptosis initiation $(81,82)$. Moreover, in neurons, mitochondrial dysfunction is also associated with increased susceptibility to excitotoxicity (i.e., cell death caused by excessive stimulation of neurons by excitatory amino acids, such as glutamate) (83).

Soluble $\mathrm{A} \beta$ peptides have been found in different organelles, and their deleterious effects are largely due to their accumulation within mitochondria. Indeed, intracellular $A \beta$ inhibits the activity of different mitochondrial respiratory enzymes, causes decreased ATP production, and increases the production of reactive oxygen species (ROS) (84-87) (Figure 2B). Moreover, A $\beta$ induces mitochondrial dysfunction by interacting with the $A \beta$-binding protein known as $\mathrm{A} \beta$-binding alcohol dehydrogenase (ABAD), which is present on the mitochondrial membrane (88). In addition, $A \beta$ accumulation impairs the permeability of mitochondrial membranes leading to the opening of mitocholdrial $\mathrm{Ca}^{2+}$ channels and mPTPs as well as the enhancement of cytochrome $c$ (Cytc) release (89). At the structural level, accumulation of soluble A $\beta$ impairs mitochondrial fusion and fission and triggers abnormalities in mitochondrial trafficking, morphology, and degradation [reviewed in Ref. (90)].

In the retina, intraocular injection of respiratory complex (I, III, and IV) inhibitors or A $\beta$ fibrils yields induction of BACE1 expression and activity, suggesting that $A \beta$-mediated mitochondrial respiratory inhibition and oxidative stress facilitate BACE1 expression (44). Interestingly, subretinal injection of A $\beta$ oligomers resulted in RPE cell hypertrophy without triggering apoptosis but yielded a significant amount of delayed photoreceptor death (91).

\section{Amyloid- $\beta$ and Glial Activation}

The presence of misfolded proteins and their aggregates causes an alteration in the receptor-ligand interactions that modulate both microglia and astroglia activity. Both microglia and astroglia release cytokines, nitric oxide, and other cytotoxic molecules after $A \beta$ exposure (Figure 2C). Astroglia regulate synapse formation and function in addition to participating in the tripartite synapse (92). It was shown that $A \beta$ upregulates $\mathrm{NF \kappa B}$ in astrocytes, leading to C3 release (93). The latter binds the neuronal G-protein-coupled receptor $\mathrm{C} 3 \mathrm{aR}$, inducing dendritic structural alterations and synaptic dysfunction. C3 also interacts with microglial $\mathrm{C} 3 \mathrm{aR}$ causing alterations in cognitive function and impairment of $\mathrm{A} \beta$ phagocytosis (94). Moreover, the exposure of astroglia to $A \beta$, favors astrogliosis, a process that leads to molecular and functional changes in astrocytes and is 


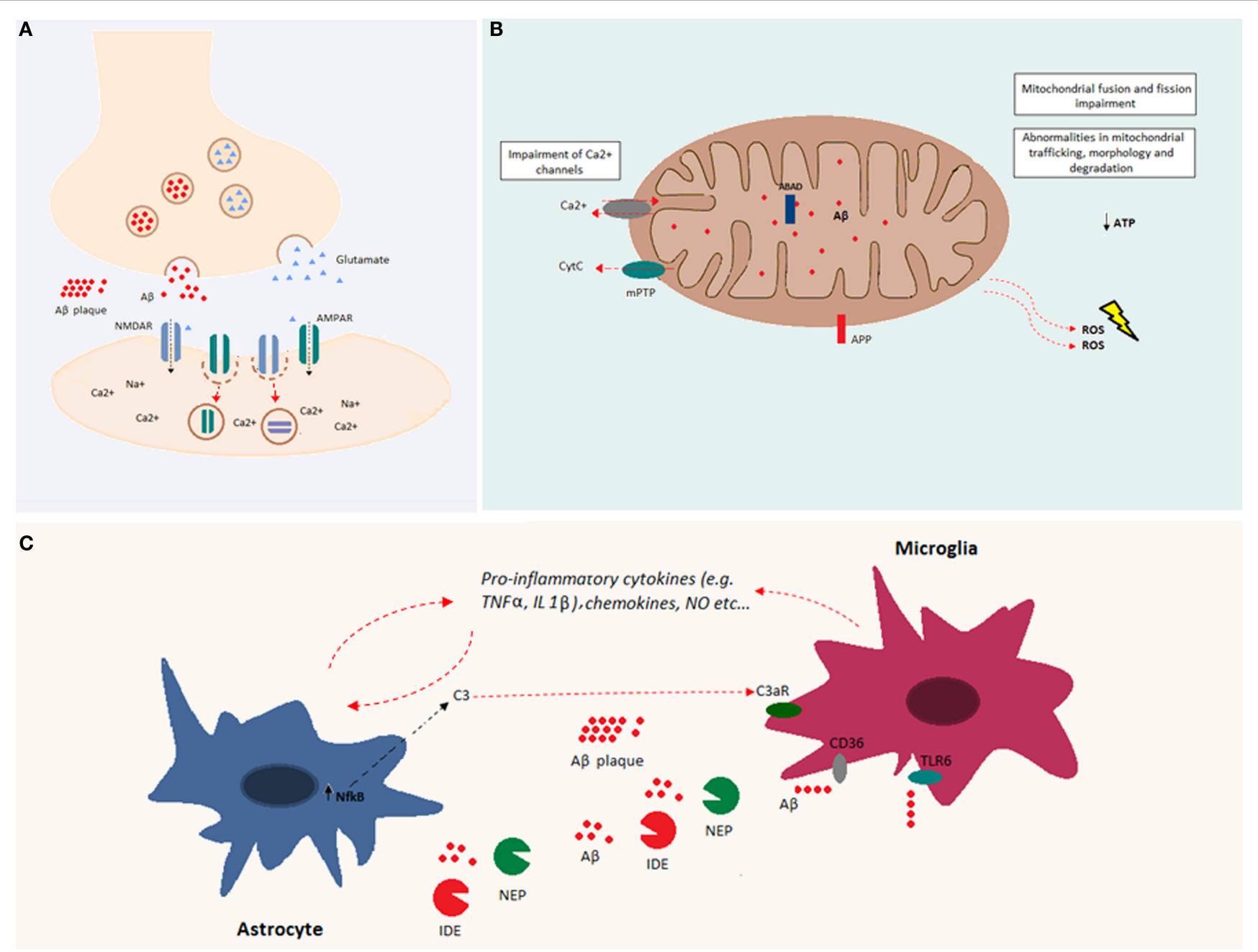

FIGURE 2 | Overview of $\mathbf{A} \boldsymbol{\beta}$ cellular effects. (A) A $\beta$ is implicated in synapse loss. Increased $A \beta$ at the synapse reduces excitatory postsynaptic transmission. Indeed, A $\beta$ oligomers reduce glutamatergic synaptic transmission by decreasing the number of both AMPA and NMDA receptors at the postsynaptic membrane. (B) A $\beta$ accumulation within the mitochondria causes impairments in fusion and fission and abnormalities in mitochondrial trafficking, morphology, and degradation. Both APP and A $\beta$ can interact with mitochondrial membranes. A $\beta$, by interacting with mitochondrial respiratory enzymes, causes decreased ATP production and increased reactive oxygen species (ROS) production. In addition, $A \beta$ binds the A $\beta$-binding alcohol dehydrogenase (ABAD), increasing its deleterious effects in mitochondrial function. Mitochondrial $\mathrm{Ca}^{2+}$ channels are impaired by $\mathrm{A} \beta$, and mitochondrial permeability transition pore (mPTP) opening gives rise to the enhancement of cytochrome $c$ (Cytc) release. (C) A $\beta$ accumulation induces glial activation. Astrocytes and microglia release cytokines, chemokines, and nitric oxide (NO) after exposure to $\mathrm{A} \beta$. Increased levels of $\mathrm{NFKB}$ in astrocytes induce the release of $\mathrm{C} 3$, which binds the $\mathrm{C} 3 a$ receptor, impairing microglia-mediated $\mathrm{A} \beta$ phagocytosis. Both microglia and astrocytes release $A \beta$-degrading proteases, such as neprilysin and insulin-degrading enzyme. $A \beta$ fibrils are degraded through microglia-dependent phagocytosis, triggered by the ligation of A $\beta$ to microglia receptors (e.g., CD36 and TLR-6).

implicated in different brain diseases (95). Furthermore, astroglia play an important role in $\mathrm{A} \beta$ clearance. Indeed, astrocytes are able to bind to and degrade $A \beta$ and release extracellular $A \beta$ degrading proteases (e.g., neprilysin, insulin-degrading enzyme, angiotensin-converting enzyme-1, and endothelin-converting enzyme-2) $(96,97)$. On the other hand, microglia are phagocytic cells ubiquitously distributed in the brain. Microglia play important roles in the maintenance and plasticity of neuronal circuits, in the surveillance for pathogens or cell debris, and in tissue maintenance (98-100). A $\beta$ oligomers and fibrils are able to bind microglia surface receptors, such as cluster of differentiation-36 (CD36), toll-like receptor (TLR)-4, and TLR-6, leading to their activation (101, 102). Activated microglia release proinflammatory cytokines and chemokines $(102,103)$. Consequently, extracellular proteases (in particular, neprylysin and the insulindegrading enzyme) are released and give rise to enzymatic degradation of soluble $A \beta$ (104). In addition, receptor ligation triggers the activation of microglial-dependent phagocytosis of $\mathrm{A} \beta$ fibrils and their degradation through the endolysosomal pathway. $A \beta$ accumulation itself leads to increased release of proinflammatory cytokines, such as tumor necrosis factor-alpha $(\mathrm{TNF} \alpha)$, interleukin (IL)- $1 \alpha$, and IL-1 $\beta(105,106)$. The massive release of proinflammatory cytokines might be associated with impairment of synaptic transmission by suppressing LTP 
(100). It has also been shown that there is a positive feedback loop between $\mathrm{TNF} \alpha$ and $\mathrm{A} \beta$, since $\mathrm{TNF} \alpha$ is able to induce $\mathrm{A} \beta$ production by increasing BACE1 expression and $\gamma$-secretase activity $(107,108)$. In addition, the use of TNF $\alpha$ inhibitors leads to a decrease in APP processing and A $\beta$ (109). Similarly, IL-1 $\beta$ increases $A \beta$ production by increasing $\gamma$-secretase activity (107). Even though the early activation of astroglia and microglia is beneficial and leads to $\mathrm{A} \beta$ clearance, in a pathological context, the sustained activation of these cells may induce a positive feedback loop between APP processing and inflammation, which is deleterious (100). Indeed, inflammation is a consequence of $A \beta$ accumulation, and as a result, inflammation contributes directly to the pathogenesis and progression of the disease.

\section{Amyloid- $\beta$ and Blood Vessels}

The pathophysiological cause and consequence of the accumulation of $A \beta$ and/or its precursor APP in the brain and the retina remain poorly understood. Twenty years ago, it was reported that coincident APP and B-cell lymphoma-2 (Bcl-2) induction may play a role in rat retinal cell survival after optic nerve and vascular injury. The underlying mechanism involves APP induction selectively in either activated astrocytes (Müller cells) or neurons (110). Microinjection of $\mathrm{A} \beta$ into the adult zebrafish eye triggers an increase in endothelial tip cells and a subsequent increase in the capillary bed density without affecting larger arterial vessels (111). In this light, the recent discovery of BACE1 expression in endothelial cells (indicating local cleavage of APP to A $\beta$ in the blood-brain barrier in mice, bovine, and humans) has attracted much interest (43). Indeed, BACE1 appears to be a critical regulator of retinal homeostasis since genetic invalidation of BACE1 in mice yields retinal thinning, apoptosis, reduced retinal vascular density, and increased accumulation of the age pigment, lipofuscin (112). The use of BACE1 inhibitors for therapeutic purposes should therefore be carefully evaluated for the putative impairment of retinal homeostasis.

Some aspects of endothelial BACE1 regulation have been elucidated, such as its induction in the presence of reduced levels of microRNA-195 (miR-195) in hypoperfusion/hypoxic conditions (113). This BACE1 induction is associated with reduced occludin expression in tight junctions of cerebral blood vessels (114). The cellular mechanism behind the deleterious effects of $A \beta$ on cerebral vessel endothelial cells involves activation of the cationic $\mathrm{Ca}^{2+}$-permeable channel transient receptor potential melastatin-2 (TRPM-2) and intracellular $\mathrm{Ca}^{2+}$ overload (115). In fact, the $A \beta$-mediated decrease in zonula occludin-1 (ZO-1) expression is attenuated by neutralizing antibodies against receptor for advanced glycation endproducts (RAGE) and inhibitors of calcineurin, suggesting that the $\mathrm{A} \beta$-RAGE interactions disrupt tight junction proteins via the $\mathrm{Ca}^{2+}$-calcineurin pathway (116).

\section{A $\beta$ AMYLOIDOSIS-RELATED RETINAL NEURODEGENERATIVE DISEASES}

Accumulation and aggregation of $A \beta$ is a common denominator of a number of neurodegenerative diseases. Some of them primarily affect the eye/retina (AMD, glaucoma), while others display more specific cerebral manifestations, such as $\mathrm{AD}$ and PD. However, evidence is accumulating in support of retinal alterations that may reflect the cerebral neurodegeneration seen in $\mathrm{AD}$ and $\mathrm{PD}$ patients.

\section{Alzheimer's Disease}

Alzheimer's disease is the main cause of dementia and the most common neurodegenerative disorder in the elderly. It is characterized by cognitive, memory, and language impairments leading to a complete loss of executive functions at the advanced stages (https://www.alz.co.uk/research/WorldAlzheimerReport2015. pdf). From a histophatological point of view, two main hallmarks of $\mathrm{AD}$ are $\mathrm{A} \beta$ plaques and neurofibrillary tangles (NFTs). The latter are mainly composed of hyperphosphorylated tau protein, a microtubule-associated protein (MAP) essential for the maintenance of neuronal polarity and structure (117). It has been shown that $A \beta$ accumulation leads to disassembly of tau from the microtubules and promotes its hyperphosphorylation $(118,119)$. The hyperphosphorylation of tau and its subsequent oligomerization results in the formation of intracellular NFTs. Ultimately, cytotoxic NFTs act in synergy with oligomeric $A \beta$ and lead to synaptic dysfunction and axonal loss $(120,121)$.

\section{AD Pathology in the Brain}

Functional alterations associated with $\mathrm{AD}$ have been extensively studied in the brain at different levels (network/circuit, cellular, subcellular, and molecular) of organization.

\section{Synaptic Dysfunction}

Amyloid-beta oligomers reduce glutamatergic synaptic transmission by decreasing the number of both AMPA and NMDA postsynaptic receptors (68-71). Besides, a small increase in A $\beta$ has been correlated with increased presynaptic transmission, implicating the activation of $\alpha 7$-nicotinic acetylcholine receptors (nAChR) $(32,122)$. These synaptic dysfunctions coincide with dysregulation of both LTP and long-term depression (LTD), which are attenuated and enhanced, respectively. Such functional impairments are accompanied with a collapse of dendritic spines and synaptic loss $(69,70,123)$. Importantly, AD is characterized by aberrant excitatory network activity and synchronization, which leads to dysfunction of learning and memory circuits and subsequent cognitive decline (124).

\section{Mitochondrial Dysfunction and Oxidative Stress}

Mitochondrial dysfunction is an early event in AD pathogenesis (87). Both APP (125) and A $\beta$ (126) are targeted to mitochondria. Mitochondrial A $\beta$ accumulation has been clearly demonstrated both in $\mathrm{AD}$ patients and in transgenic $\mathrm{AD}$ mouse models $(127,128)$. However, the precise mitochondrial actions of $\mathrm{A} \beta$ are still poorly understood. In particular, it is unknown whether mitochondrial translocation of intracellular $A \beta$ is required for the inhibitory effects on mitochondrial membrane potential (MMP) and ATP levels recently demonstrated in a transgenic mouse AD model (TgAPP/PS1) (129). Besides, it has been suggested that $A \beta$ cooperates synergistically with tau in the impairment of oxidative phosphorylation (86). Indeed, several mitochondrial 
respiratory enzymes were found to be altered in $\mathrm{AD}$, leading to impairments in energy metabolism (130), but the cause-effect relationship between these impairments and $A \beta$ has not been entirely elucidated.

\section{Neuroinflammation}

Prominent glial cell activation and related neuroinflammation are seen at the advanced stages of $\mathrm{AD}$ and likely play a pivotal role in $\mathrm{AD}$ progression (100). The aggregation of both $\mathrm{A} \beta$ and tau protein leads to the activation of microglia and astroglia, which are consistently found surrounding $A \beta$ deposits in postmortem AD brains (131-133). More recently, positron emission tomography (PET) brought additional in vivo evidence for $\mathrm{AD}$-associated cerebral microgliosis (134).

Accordingly, evidence of neuroinflammation was present in all studied AD mouse models (65). In particular, a prominent induction of TNF $\alpha$ and shift from phagocytic M2 toward the cytotoxic-like M1 microglia phenotype has been reported in the hippocampus at the overt stages of AD pathology in TgAPP/PS1 mice, and this effect was reproduced by treating microglia cultures with oligomeric $A \beta$ (135). This upregulation is accompanied by the coincident induction of another major proinflammatory cytokine, IL-1 $\beta$, not only in the TgAPP/PS1 mouse $(136,137)$ but also in Tg2576 (138), 3xTg (139), and TgCRND8 (140) mice. Most importantly, all these studies confirmed consistent and concomitant microglia and astrocyte activation.

The microglia M1-like activation state is characterized by uncontrolled proinflammatory cytokine and chemokine secretion, inefficient $\mathrm{A} \beta$ phagocytosis, and TLR activation, which further fuels neuroinflammation (65). Among the relevant cytokines and chemokines, monocyte chemoattractant protein (MCP-1) was repeatedly implicated. The membrane pore-forming capacity of $\mathrm{A} \beta$ oligomers has also been related to neuroinflammation (141). Classically, deleterious neuroinflammatory environments exacerbate $\mathrm{AD}$-related pathological alterations and have been consistently involved in $\mathrm{AD}$ progression. However, evidence is mounting to suggest that neuroinflammation likely also occurs before significant A $\beta$ accumulation (142). Moreover, proinflammatory alterations related to the upregulation of TNF $\alpha$ in the context of partial microglia activation may occur even before $\mathrm{A} \beta$ accumulation (143).

\section{Amyloid Microangiopathy}

Microangiopathy, which comprises a host of pathological alterations in the small blood vessels (arterioles, venules, and capillaries), is closely related to cerebral small vessel disease (CSVD). These are heterogeneous pathological conditions that include cerebral blood flow deregulation, endothelial activation, and blood-brain barrier disruption (144).

Such pathological alterations are also found in cerebral amyloid microangiopathy (145). This particular form of microangiopathy results from $\mathrm{A} \beta$ deposition within the walls of capillaries or immediately in the adjacent brain parenchyma $(145,146)$. According to an emerging concept, these lesions may play a causal role in cerebral dysfunction and precede AD-related cognitive impairments (146). Remarkably, although A $\beta$ accumulates selectively in arterioles, the cortical vasculature network appears to be altered in TgCRND8 mice. Extensive structural and functional alterations were observed, including vessel coiling and looping, increased tortuosity of the venules (but not arterioles), and altered microvascular network cerebral blood flow response to hypercapnia (147).

Another prominent feature of AD-related amyloid microangiopathy is the presence of microbleeds. In the $\operatorname{Tg} 2576$ mouse model of $\mathrm{AD}$, these microbleeds are due to leakage or rupture of microvasculature in brain regions affected by vascular amyloid deposits (148). Such microbleeds may be related to the upregulation of BACE1 observed in endothelial cells of the blood-brain barrier in another mouse AD model (43) as well as AD patients (114). The knockdown of miR-195, which regulates BACE1 expression at least in endothelial cells, yields increased tau phosphorylation at Ser202/Thr205, Ser262, Thr231, and Ser422, as well as Cdk5/p25 activation in the rat hippocampus (113).

\section{AD Pathology in the Retina}

The accumulation of $\mathrm{A} \beta$ and its deposition into $\mathrm{A} \beta$ plaques have been found in postmortem retinas from $\mathrm{AD}$ patients (9). In addition, visual disturbances are common in $\mathrm{AD}$, and they may be due to local retinal abnormalities rather than exclusively related to central, visual cortex alterations (149). However, the molecular mechanisms underlying these visual disturbances and the role that $\mathrm{A} \beta$ may play in the retina are still largely unknown. Structural abnormalities identified in retinas of $\mathrm{AD}$ patients include reduced number of optic nerve fibers and altered thickness of the parapapillary and macular RNFL $(150,151)$. These structural changes likely reflect retinal neurodegeneration, such as RGC death (152), and are further associated with optic nerve damage (153).

Consistently, $A \beta$ plaques have also been found in the retina of AD transgenic mouse models (9). Retinas from APP transgenic mouse strains contain $18-70 \mathrm{kDa}$ proteolytic products from APP. The proportion of $\alpha$-secretase generated C-terminal fragments in transgenic retinas was higher than the fragments generated from $\beta$-secretase. However, in ELISA assays, retinal A $\beta 1-42$ was 75 times lower than in transgenic brains and remains undetectable by western blot, indicating that much less $A \beta$ is generated in the retina compared with the brain (154). The age-dependent increase in plaques in the outer and inner plexiform layers (OPL/ IPL), INL/ONL, and ganglion cell layer (GCL) (155) coincides only partly with the upregulation of APP, which is seen only in the RGC and INL regions (149). In line with these data, transgenic $\mathrm{AD}$ mice display both neuroinflammation and neurodegeneration mostly in the GCL $(152,156)$, where they correlate with APP induction and $A \beta$ accumulation (149).

Interestingly, a recent study showed that amyloidopathy occurs in the retina prior to the brain in TgAPP/PS1 mice, suggesting that in $\mathrm{AD}$ patients, $\mathrm{A} \beta$ deposits may also be detected in the retina prior to the brain (10). The study of retinal amyloidopathy may be useful, not only to understand the molecular mechanisms involved in $\mathrm{AD}$ but also to search for early-stage $\mathrm{AD}$-related biomarkers. This prospect is even more interesting, considering the possibility of developing a non-invasive method to diagnose early-stage $\mathrm{AD}$ through direct retinal imaging. 


\section{Synaptic Dysfunction in the Retina}

Available data concerning AD-related retinal synaptic dysfunctions come exclusively from electroretinogram (ERG) recordings, which give insight into the global electrical response of the retina to a light stimulus. ERGs performed in $\mathrm{AD}$ patients at the advanced stages of pathology revealed a significant reduction in the amplitudes of a- and b-waves as well as an increased latency of the response $(156,157)$. Analogous data have been reported in the aged TgAPP/PS1 mouse model (155). However, while ERG recordings provide a rough estimate of the $\mathrm{AD}$-dependent impairments in glutamate-mediated excitatory neurotransmission in the retina, they do not decipher the underlying mechanisms. Cellular electrophysiology studies (field-recording, patch-clamp) are needed in order to precisely define the neurochemical type of synapses and neurons that are the main targets of $\mathrm{A} \beta$.

\section{Neuroinflammation in the Retina}

The accumulation of $A \beta$ deposits with age in the retina of a transgenic mouse model of $\mathrm{AD}$ is accompanied by an increase in immunoreactivity for MCP-1 and F4/80, which suggests that resident microglia are activated, as well as an increase in terminal deoxynucleotidyl transferase dUTP nick end labeling (TUNEL)positive profiles in the GCL (149). These results suggest that $\mathrm{A} \beta$-induced neurodegeneration is associated with neuroinflammation (149).

The subretinal microinjection of $\mathrm{A} \beta$ yields an adaptive, local inflammatory response, which consists of altered expression patterns of cyclooxygenase-2 (COX-2), glutamine synthetase (GS), inwardly rectifying potassium (Kir) channel Kir4.1, and aquaporin (AQP)-4 water channels in retinal Müller glia cells and of AQP-1 in photoreceptors. Activation of the CCL2/CCR2 chemokine axis, along with microglia activation and migration, is also detectable in this paradigm, whereas its inhibition provides neuroprotection against the deleterious actions of $\mathrm{A} \beta$ (158). Moreover, A $\beta$ triggers gliosis characterized by glial fibrillary acidic protein (GFAP), vimentin, and nestin upregulation in Müller cells (159). These alterations are similar to those seen during neuroinflammation in the brain.

The upregulation of GFAP was further confirmed after A $\beta$ injection into the vitreous fluid (160) in both acute (48 h) and delayed (5 months) settings. Remarkably, this study demonstrated a concomitant and selective loss of parvalbumin-expressing neurons in the INL and, to a lower extent, in the GCL (160). The latter finding suggests that, as in the AD brain (161) and transgenic AD mouse models $(162,163)$, parvalbumin-expressing inhibitory neurons in the retina may be the most vulnerable to $A \beta$.

\section{Mitochondrial Dysfunction and Oxidative Stress in the Retina}

The neuroinflammation triggered by subretinal injection of $\mathrm{A} \beta$ was accompanied by oxidative stress in the inner and outer retinal segments with an increase in highly reactive unsaturated aldehydes 4-hydroxy 2-non-enal (HNE) and acrolein as well as in 8-hydroxy-2'-deoxyguanosine (8-OHdG), a measure of oxidative damage to DNA (159), which culminated in photoreceptor cell death $(158,159)$. Accordingly, an inverse approach consisting of intravitreous injection of mitochondrial respiratory complex inhibitors confirmed that inhibition of mitochondrial function and associated oxidative stress resulted in increased APP processing and $A \beta$ accumulation. The latter alterations were also found to be accompanied with GFAP upregulation and glial activation (44).

\section{Amyloid Microangiopathy}

Amyloid-beta accumulation has been found in the retinal and choroidal vasculature of $\mathrm{AD}$ mouse models, suggesting that $\mathrm{A} \beta$ may be implicated in alterations in local blood flow (149). Moreover, retinal veins in $\mathrm{AD}$ patients are narrowed, and the retinal blood flow is decreased (164). Most importantly, a very large case-controlled study (213 AD patients and 294 cognitively normal controls) of retinal microvasculature networks reported a significant decrease in the branching pattern index (fractal dimension) of the retinal venular tree and arteriolar tortuosity in patients (165). Taken together, recent studies in the brain and retina point to similar alterations in the microvasculature in mouse models and AD patients. Furthermore, retinal microvasculature alterations, accessible to non-invasive imaging, may reflect those occurring in the brain. In line with this assumption, abnormal retinal blood flow has been correlated with degree of cognitive impairment (AD versus $\mathrm{MCI}$ versus control subjects), suggesting that blood flow abnormalities may precede $\mathrm{AD}$-related neurodegeneration (166).

\section{Age-Related Macular Degeneration}

Age-related macular degeneration is an age-related retinal degenerative disease that causes irreversible vision loss. It is estimated that up to 50 million people worldwide are affected by AMD, and in western countries 5-10\% of individuals over 60 years of age suffer from this disorder (167). AMD is characterized by the build-up of drusen deposits between the Bruch's membrane (BM) and the RPE, which lead to RPE cell abnormalities, dysfunction of the choroidal blood-eye barrier, and photoreceptor death (168, 169). The most common form of AMD is dry AMD, characterized by thickening of the BM, formation of drusen deposits, and activation of the innate immune response (170). The dry form may progress into the exudative (or wet) form, which is characterized by choroidal neovascularization and retinal edema (171). In some cases, drusen deposits continue to expand and can coalesce, giving rise to the degeneration of a large area of RPE and photoreceptors in a process known as geographic atrophy. Drusen is extracellular deposits composed of different proteins, including $A \beta$ and complement members (172). The mechanism leading to drusen formation is still unclear but may involve the accumulation of toxic by-products of the phototransduction cycle (173). These toxic by-products cause oxidative stress and inflammation, which play a central role in AMD progression (42, 174-177). Drusen-associated amyloidogenic proteins have recently been identified as oligomers (172).

Retinal cells that overlie both soft and hard drusen display numerous structural and molecular abnormalities. Normally detectable only in the outer segments of rod photoreceptors, rod opsin immunolabeling was also observed in the inner segment, cell body, axon, and axon terminal of photoreceptors that overlie drusen (178). 
Similar to AD, the risk of developing AMD is also linked to some apolipoprotein E (APOE) polymorphisms. However, in contrast to $\mathrm{AD}$, it has been shown that the e4 allele of the gene encoding APOE is associated with a lower risk of developing $\mathrm{AMD}$, while the e2 allele is associated with a higher risk. Other polymorphisms associated with the development of AMD are linked to genes encoding components of the complement system (170). The polymorphism $\mathrm{Y} 402 \mathrm{H}$ in complement factor $\mathrm{H}(\mathrm{CFH})$, for example, is the first genetic risk factor for both forms of AMD (179-181). It occurs in 33\% of individuals and is associated with a $48 \%$ risk for developing AMD (182). CFH is the main inhibitor of the alternative pathway, a key component of the innate immune response. $c f h \mathrm{KO}$ mice also show features of AMD (183). The mechanisms by which CFH and polymorphisms in the gene affect AMD remain unknown. In 2016, the CFH Y402H polymorphism was identified as a risk factor for $\mathrm{AD}$ in a very large cohort of patients (184), confirming previous studies (185).

\section{Synaptic Dysfunctions}

There is currently no data on putative synaptic dysfunctions in AMD. This may be related to the fact that the main target of neurodegeneration in AMD is the RPE, which is not part of the neuronal network sensu stricto. However, RPE cells are excitable, and it would be interesting to explore $A \beta$-related effects on their excitability.

Drusen-associated abnormalities in the synaptic terminals of photoreceptor neurons have been reported. In AMD-afflicted retinas, but not in normal aged human retinas, a large number of photoreceptor synapses across the entire retina retract into the ONL. This event evokes the subsequent outgrowth of dendrites from postsynaptic bipolar cells, again across the entire retina, and the subsequent rearrangement of synaptic contacts between the photoreceptor and bipolar cells. In addition, an increase in intermediate filament protein immunoreactivity (vimentin and GFAP) is observed within Müller glial cells in areas of the retina overlying drusen. However, other types of retinal neurons (i.e., bipolar, horizontal, amacrine, and ganglion cells) are all, at least structurally, unaffected (186).

\section{Mitochondrial Dysfunction and Oxidative Stress}

In AMD, the accumulation of lipofuscin, i.e., cross-linked pigmentary deposits from photoreceptor membranes, favors RPE degeneration. Lipofuscin has damaging oxidant properties and has been associated with mitochondrial dysfunction. Similar to what happens within the brain, $A \beta$ accumulation may further exacerbate this state of metabolic and oxidative stress (170). Analogously, A $\beta$ accumulation may contribute to mitochondrial dysfunction in RGCs. Indeed, intracellular $A \beta$ has also been observed in these cells, and it is likely that $A \beta$ interferes with mitochondrial function, following the mechanisms characterized in $\mathrm{AD}$ (37).

\section{Neuroinflammation}

Drusen formation leads to activation of the innate immune system and also to oxidative and metabolic stress, which progressively leads to neurodegeneration. Increased deposition of $\mathrm{A} \beta$ has been found in photoreceptor outer segments and in the membrane between the RPE and the BM, in the retinas of both aging humans and mice (51). It has been proposed that along with aging, gradual accumulation of debris may initiate the formation of drusen, which encapsulates different types of proteins, lipids, and inflammatory molecules (176). Among these proteins, extracellular $A \beta$ derived from injured RPE may be included in drusen. Still, the role A $\beta$ plays in this context is unclear. It has been shown that the oligomeric form of $A \beta 1-42$ is implicated in the increased production of ROS, the alteration of RPE cell structure, and transepithelial permeability (91). In addition, A $\beta$ may enhance the release of vascular endothelial growth factor (VEGF) and pigment epithelium-derived factor from RPE cells, favoring angiogenesis (187).

\section{Amyloid Microangiopathy}

Amyloid microangiopathy has not been extensively studied in AMD. However, it has been proposed that microvascular leakiness may be caused by the promoting effect that amyloidogenesis may exert on neoangiogenesis. VEGF-mediated angiopathy plays a key role in choroidal neovascularization, which is a hallmark of exudative AMD (188). On the other hand, increased VEGF levels may be triggered by members of the complement system, such as C3a and C5a (189). It remains to be determined what triggers the activation of the complement system. Similar to what happens in $\mathrm{AD}, \mathrm{A} \beta$ may promote its activation (190).

The activated complement system may in turn lead to increased vascular permeability and hypervascularization. This scenario has been experimentally verified in aged $\mathrm{Tg} 2576$ mice and postmortem AD brain tissue (191). Neovascularization is a major hallmark of exudative AMD, and by consequence, this form of $\mathrm{AMD}$ and $\mathrm{AD}$ may share pathological mechanisms in the context of blood-brain barrier impairments. However, a recent study (including 107 individuals diagnosed with AMD) reported no difference between venular and arteriolar calibers in the macula region, at least during the early stages of AMD (192) in agreement with a previous study (193).

\section{Glaucoma}

Glaucoma is a progressive optic neuropathy that represents one of the leading causes of blindness worldwide. It is characterized by the loss of RGC neurons and their axons, with consequent structural changes in the optic nerve and visual field defects. The entire visual pathway, including intracranial optic nerve, lateral geniculate nucleus, and visual cortex, is affected $(5,194,195)$. Therefore, glaucoma can be associated with other neurodegenerative disorders, such as $\mathrm{AD}$, since the most vulnerable neuronal target (i.e., RGCs) is common for both pathologies.

One of the major risk factors for developing glaucoma is chronically elevated intraocular pressure (IOP). Accordingly, it has been shown that elevated IOP leads to ganglion cell changes that promote caspase activation and abnormal APP processing (196). Reducing IOP is the only therapy available to limit disease progression; however, the correlation between glaucoma and IOP has only been partially elucidated, and other factors clearly contribute to its pathogenesis $(197,198)$. Indeed, reducing IOP does not always stop disease progression (199), and some primary open-angle glaucoma patients show normal IOP (200). 
It is presently unknown if $A \beta$ is among the additional factors involved in the observed changes in IOP during glaucoma. Nevertheless, $A \beta$ does appear to be a common denominator for glaucoma and $\mathrm{AD}$. Indeed, in glaucoma patients, the level of $\mathrm{A} \beta$ in the vitreous fluid is decreased, while tau protein is increased (201). Similarly, in AD patients, the level of A $\beta$ in the cerebrospinal fluid (CSF) is decreased, because of its reduced clearance, whereas tau protein is increased (202). In addition, increased levels of $A \beta$ have been observed in RGCs in rat models of acute ocular hypertension $(196,203)$. Moreover, inhibiting A $\beta$ production or improving its clearance reduced RGC death (203).

\section{Synaptic Dysfunction}

Mechanisms of synaptic dysfunction in glaucoma have not yet been investigated.

\section{Mitochondrial Dysfunction and Oxidative Stress}

Glaucoma has been shown to involve mitochondrial dysfunction (204), and oxidatively modified DNA, proteins, and lipids have been identified in affected patients (205). Importantly, the plasma level of F2-isoprostane lipid was correlated with heat shock protein 72 (HSP72) and heme-oxygenase-1, which are both known to be involved in the defense response against oxidative stress and are increased in glaucoma patients (206).

\section{Neuroinflammation}

Transcripts of TNF $\alpha$, IL-2, and IL- 6 have been identified in the iris of neovascular glaucoma patients (207). The role of retinal gliaderived proinflammatory cytokines, notably IL-1 $\beta$ and TNF $\alpha$, in glaucoma has been broadly recognized (208). Important insights into neuroinflammation-related mechanisms of glaucoma have been recently obtained in an elegant study using a rat model of glaucoma. The dominant-negative TNF $\alpha$ inhibitor, XPro1595, which selectively inhibits soluble $\mathrm{TNF} \alpha$, rescued Müller cell and microglia/macrophage activation after induction of ocular hypertension. Moreover, XPro1595 also prevented the TNF $\alpha$ mediated induction of the $\mathrm{Ca}^{2+}$-permeable GluR2 subunit of AMPA glutamate receptors, which are known to be causal in the cytotoxic effects of TNF $\alpha$, as well as in the death of RGC neurons (209). These data formally demonstrate the causal link between neuroinflammation and neurodegeneration in glaucoma.

\section{Amyloid Microangiopathy}

To date, putative $\mathrm{A} \beta$-related structural and functional alterations of microvessels have not been investigated in glaucoma. Indeed, a host of publications (more than 2000 referenced in PubMed) deal with hemodynamic alterations that are consistently found in glaucoma (210). However, endothelin-1 and nitric oxide, known to be released by endothelial cells upon activation, are increased in open-angle glaucoma, suggesting the possible involvement of microvasculature in this pathology (210).

\section{CONCLUSION}

Based on the evidence discussed in this review, it is increasingly clear that, at least in the case of $\mathrm{A} \beta$-amyloidosis, the deleterious effects that $A \beta$ exerts on both cerebral and retinal neurons are very similar. These similarities concern alterations at both the cellular and molecular levels, such as cytokine induction and mitochondrial failure, regardless of the particular disease. Furthermore, $\mathrm{A} \beta$-related alterations, such as oxidative stress, microvasculature abnormalities, and neuroinflammation, are more related to amyloidosis than to the pathological context specific to each disorder (e.g., the different composition of $\mathrm{A} \beta$ plaques and drusen in $\mathrm{AD}$ and AMD).

Amyloid-beta may therefore be an attractive common target for immunotherapy in both AMD and AD. Encouraging results were obtained after administration of anti-A $\beta$ antibodies in mouse models of AMD (211) and AD (212) that motivated human clinical trials, in spite of some secondary effects. Although the first-generation of $\mathrm{A} \beta$ vaccines in $\mathrm{AD}$ was interrupted because of severe cerebral hemorrhage (213), new molecules are currently in clinical trials. In particular, GSK933776 was effective in both AMD phase II (214) and AD phase I (215) trials. These clinical data further point to common mechanisms in AD and AMD. Consistently, treatment with an anti-A $\beta$ antibody in a mouse model of AMD yielded a decrease in $A \beta$ deposits both in the retina and the brain (211).

At this stage, many challenges remain for the future. For example, it is of utmost importance to determine whether a coincident oligopathy, such as the PD-associated $\alpha$-synuclein amyloidosis, may affect $\mathrm{A} \beta$-amyloidosis output in the retina. Understanding whether these two amyloidoses yield additive or synergistic pathological alterations may be very helpful for designing new and more global therapeutic approaches for all relevant diseases.

It is now largely recognized that neurodegenerative alterations in the retina reflect those occurring in the brain, thus raising the hope of using the retina as a source of diagnostic biomarkers for cerebral neurodegeneration. The retina has attracted much interest since, when compared with the brain, it displays the advantage of being relatively less complex structurally and more accessible to non-invasive exploration. Indeed, it may 1 day be possible to use the retina as a proxy to diagnose early neurodegenerative alterations in the brain to target them before neurodegeneration becomes irreversible.

\section{AUTHOR CONTRIBUTIONS}

AM wrote the first draft of the manuscript, managed the references, and prepared the Figure 2. VD prepared the Figure 1 and brought constructive changes to the text of the manuscript. CC significantly reviewed the text and worked on references indexing. FM made the major modifications in the course of successive reviewing. SK conceived and supervised the preparation of the review.

\section{FUNDING}

The research leading to this review has received funding from the Fondation pour la Recherche Médicale FRM DVS20131228910 and the Service de Coopération et d'Action Culturelle du Consulat Général de France à Québec 65502 (Coopération France-Québec) to SK. 


\section{REFERENCES}

1. Krantic S, Torriglia A. Retina: source of the earliest biomarkers for Alzheimer's disease? J Alzheimers Dis (2014) 40(2):237-43. doi:10.3233/ JAD-132105

2. Nalivaeva NN, Belyaev ND, Kerridge C, Turner AJ. Amyloid-clearing proteins and their epigenetic regulation as a therapeutic target in Alzheimer's disease. Front Aging Neurosci (2014) 6:235. doi:10.3389/fnagi. 2014.00235

3. Surguchev A, Surguchov A. Conformational diseases: looking into the eyes. Brain Res Bull (2010) 81(1):12-24. doi:10.1016/j.brainresbull.2009.09.015

4. Blanks JC, Torigoe Y, Hinton DR, Blanks RH. Retinal pathology in Alzheimer's disease. I. Ganglion cell loss in foveal/parafoveal retina. Neurobiol Aging (1996) 17(3):377-84. doi:10.1016/0197-4580(96)00010-3

5. Nucci C, Martucci A, Cesareo M, Mancino R, Russo R, Bagetta G, et al. Brain involvement in glaucoma: advanced neuroimaging for understanding and monitoring a new target for therapy. Curr Opin Pharmacol (2013) 13(1):128-33. doi:10.1016/j.coph.2012.08.004

6. Mailankody P, Battu R, Khanna A, Lenka A, Yadav R, Pal PK. Optical coherence tomography as a tool to evaluate retinal changes in Parkinson's disease. Parkinsonism Relat Disord (2015) 21(10):1164-9. doi:10.1016/j. parkreldis.2015.08.002

7. Forloni G, Artuso V, La Vitola P, Balducci C. Oligomeropathies and pathogenesis of Alzheimer and Parkinson's diseases. Mov Disord (2016) 31(6):771-81. doi: $10.1002 / \mathrm{mds} .26624$

8. Ho CY, Troncoso JC, Knox D, Stark W, Eberhart CG. Beta-amyloid, phospho-tau and alpha-synuclein deposits similar to those in the brain are not identified in the eyes of Alzheimer's and Parkinson's disease patients. Brain Pathol (2014) 24(1):25-32. doi:10.1111/bpa.12070

9. Koronyo-Hamaoui M, Koronyo Y, Ljubimov AV, Miller CA, Ko MK, Black KL, et al. Identification of amyloid plaques in retinas from Alzheimer's patients and noninvasive in vivo optical imaging of retinal plaques in a mouse model. Neuroimage (2011) 54(Suppl 1):S204-17. doi:10.1016/j. neuroimage.2010.06.020

10. More SS, Vince R. Hyperspectral imaging signatures detect amyloidopathy in Alzheimer's mouse retina well before onset of cognitive decline. ACS Chem Neurosci (2015) 6(2):306-15. doi:10.1021/cn500242z

11. Bertrand E, Lewandowska E, Stepien T, Szpak GM, Pasennik E, Modzelewska J. Amyloid angiopathy in idiopathic Parkinson's disease. Immunohistochemical and ultrastructural study. Folia Neuropathol (2008) 46(4):255-70

12. Chorostecki J, Seraji-Bozorgzad N, Shah A, Bao F, Bao G, George E, et al. Characterization of retinal architecture in Parkinson's disease. J Neurol Sci (2015) 355(1-2):44-8. doi:10.1016/j.jns.2015.05.007

13. Satue M, Seral M, Otin S, Alarcia R, Herrero R, Bambo MP, et al. Retinal thinning and correlation with functional disability in patients with Parkinson's disease. Br J Ophthalmol (2014) 98(3):350-5. doi:10.1136/ bjophthalmol-2013-304152

14. Huang YM, Yin ZQ. Minor retinal degeneration in Parkinson's disease. Med Hypotheses (2011) 76(2):194-6. doi:10.1016/j.mehy.2010.09.016

15. Jacobsen KT, Iverfeldt K. Amyloid precursor protein and its homologues: a family of proteolysis-dependent receptors. Cell Mol Life Sci (2009) 66(14):2299-318. doi:10.1007/s00018-009-0020-8

16. Niederwolfsgruber E, Schmitt TL, Blasko I, Trieb K, Steger MM, Maczek C, et al. The production of the Alzheimer amyloid precursor protein (APP) in extraneuronal tissue does not increase in old age. J Gerontol A Biol Sci Med Sci (1998) 53(3):B186-90. doi:10.1093/gerona/53A.3.B186

17. Liu X, Yu X, Zack DJ, Zhu H, Qian J. TiGER: a database for tissue-specific gene expression and regulation. BMC Bioinformatics (2008) 9:271. doi:10.1186/1471-2105-9-271

18. Clarris HJ, Key B, Beyreuther K, Masters CL, Small DH. Expression of the amyloid protein precursor of Alzheimer's disease in the developing rat olfactory system. Brain Res Dev Brain Res (1995) 88(1):87-95. doi:10.1016/0165-3806(95)00083-P

19. Apelt J, Schliebs R, Beck M, Rossner S, Bigl V. Expression of amyloid precursor protein mRNA isoforms in rat brain is differentially regulated during postnatal maturation and by cholinergic activity. Int J Dev Neurosci (1997) 15(1):95-112. doi:10.1016/S0736-5748(96)00073-1
20. Rohan de Silva HA, Jen A, Wickenden C, Jen LS, Wilkinson SL, Patel AJ. Cell-specific expression of beta-amyloid precursor protein isoform mRNAs and proteins in neurons and astrocytes. Brain Res Mol Brain Res (1997) 47(1-2):147-56. doi:10.1016/S0169-328X(97)00045-4

21. Yamazaki T, Koo EH, Selkoe DJ. Trafficking of cell-surface amyloid betaprotein precursor. II. Endocytosis, recycling and lysosomal targeting detected by immunolocalization. J Cell Sci (1996) 109(Pt 5):999-1008.

22. Thinakaran G, Koo EH. Amyloid precursor protein trafficking, processing, and function. JBiol Chem (2008) 283(44):29615-9. doi:10.1074/jbc. R800019200

23. Chow VW, Mattson MP, Wong PC, Gleichmann M. An overview of APP processing enzymes and products. Neuromolecular Med (2010) 12(1):1-12. doi:10.1007/s12017-009-8104-z

24. Fahrenholz F, Gilbert S, Kojro E, Lammich S, Postina R. Alpha-secretase activity of the disintegrin metalloprotease ADAM 10. Influences of domain structure. Ann N Y Acad Sci (2000) 920:215-22. doi:10.1111/j.1749-6632.2000. tb06925.x

25. Asai M, Hattori C, Szabo B, Sasagawa N, Maruyama K, Tanuma S, et al. Putative function of ADAM9, ADAM10, and ADAM17 as APP alphasecretase. Biochem Biophys Res Commun (2003) 301(1):231-5. doi:10.1016/ S0006-291X(02)02999-6

26. Tanabe C, Hotoda N, Sasagawa N, Sehara-Fujisawa A, Maruyama K, Ishiura S. ADAM19 is tightly associated with constitutive Alzheimer's disease APP alpha-secretase in A172 cells. Biochem Biophys Res Commun (2007) 352(1):111-7. doi:10.1016/j.bbrc.2006.10.181

27. De Strooper B, Annaert W. Proteolytic processing and cell biological functions of the amyloid precursor protein. J Cell Sci (2000) 113(Pt 11):1857-70.

28. Wolfe MS. Inhibition and modulation of gamma-secretase for Alzheimer's disease. Neurotherapeutics (2008) 5(3):391-8. doi:10.1016/j.nurt.2008.05.010

29. Dawkins E, Small DH. Insights into the physiological function of the beta-amyloid precursor protein: beyond Alzheimer's disease. J Neurochem (2014) 129(5):756-69. doi:10.1111/jnc.12675

30. Ring S, Weyer SW, Kilian SB, Waldron E, Pietrzik CU, Filippov MA, et al. The secreted beta-amyloid precursor protein ectodomain APPs alpha is sufficient to rescue the anatomical, behavioral, and electrophysiological abnormalities of APP-deficient mice. INeurosci (2007) 27(29):7817-26. doi:10.1523/ JNEUROSCI.1026-07.2007

31. Kamenetz F, Tomita T, Hsieh H, Seabrook G, Borchelt D, Iwatsubo T, et al. APP processing and synaptic function. Neuron (2003) 37(6):925-37. doi:10.1016/S0896-6273(03)00124-7

32. Abramov E, Dolev I, Fogel H, Ciccotosto GD, Ruff E, Slutsky I. Amyloidbeta as a positive endogenous regulator of release probability at hippocampal synapses. Nat Neurosci (2009) 12(12):1567-76. doi:10.1038/nn.2433

33. Yao ZX, Papadopoulos V. Function of beta-amyloid in cholesterol transport: a lead to neurotoxicity. FASEB J (2002) 16(12):1677-9. doi:10.1096/ f.02-0285fie

34. Grimm MO, Grimm HS, Hartmann T. Amyloid beta as a regulator of lipid homeostasis. Trends Mol Med (2007) 13(8):337-44. doi:10.1016/j. molmed.2007.06.004

35. Grimm MO, Grimm HS, Patzold AJ, Zinser EG, Halonen R, Duering M, et al. Regulation of cholesterol and sphingomyelin metabolism by amyloid-beta and presenilin. Nat Cell Biol (2005) 7(11):1118-23. doi:10.1038/ncb1313

36. Lillien L. Neurogenesis in the vertebrate retina. Perspect Dev Neurobiol (1994) 2(2):175-82.

37. Chiu K, Chan TF, Wu A, Leung IY, So KF, Chang RC. Neurodegeneration of the retina in mouse models of Alzheimer's disease: what can we learn from the retina? Age (Dordr) (2012) 34(3):633-49. doi:10.1007/s11357011-9260-2

38. Ratnayaka JA, Serpell LC, Lotery AJ. Dementia of the eye: the role of amyloid beta in retinal degeneration. Eye (Lond) (2015) 29(8):1013-26. doi:10.1038/ eye. 2015.100

39. Dinet V, An N, Ciccotosto GD, Bruban J, Maoui A, Bellingham SA, et al. APP involvement in retinogenesis of mice. Acta Neuropathol (2011) 121(3):351-63. doi:10.1007/s00401-010-0762-2

40. Ho T, Vessey KA, Cappai R, Dinet V, Mascarelli F, Ciccotosto GD, et al. Amyloid precursor protein is required for normal function of the rod and cone pathways in the mouse retina. PLoS One (2012) 7(1):e29892. doi:10.1371/journal.pone.0029892 
41. Morin PJ, Abraham CR, Amaratunga A, Johnson RJ, Huber G, Sandell JH, et al. Amyloid precursor protein is synthesized by retinal ganglion cells, rapidly transported to the optic nerve plasma membrane and nerve terminals, and metabolized. J Neurochem (1993) 61(2):464-73. doi:10.1111/j.1471-4159.1993.tb02147.x

42. Loffler KU, Edward DP, Tso MO. Immunoreactivity against tau, amyloid precursor protein, and beta-amyloid in the human retina. Invest Ophthalmol Vis Sci (1995) 36(1):24-31.

43. Devraj K, Poznanovic S, Spahn C, Schwall G, Harter PN, Mittelbronn M, et al. BACE-1 is expressed in the blood-brain barrier endothelium and is upregulated in a murine model of Alzheimer's disease. J Cereb Blood Flow Metab (2016) 36(7):1281-94. doi:10.1177/0271678X15606463

44. Xiong K, Cai H, Luo XG, Struble RG, Clough RW, Yan XX. Mitochondrial respiratory inhibition and oxidative stress elevate beta-secretase (BACE1) proteins and activity in vivo in the rat retina. Exp Brain Res (2007) 181(3):435-46. doi:10.1007/s00221-007-0943-y

45. Frederikse PH, Dubin RA, Haynes JI II, Piatigorsky J. Structure and alternate tissue-preferred transcription initiation of the mouse alpha B-crystallin/ small heat shock protein gene. Nucleic Acids Res (1994) 22(25):5686-94. doi:10.1093/nar/22.25.5686

46. Goldstein LE, Muffat JA, Cherny RA, Moir RD, Ericsson MH, Huang X, et al. Cytosolic beta-amyloid deposition and supranuclear cataracts in lenses from people with Alzheimer's disease. Lancet (2003) 361(9365):1258-65. doi:10.1016/S0140-6736(03)12981-9

47. Yoneda S, Hara H, Hirata A, Fukushima M, Inomata Y, Tanihara H. Vitreous fluid levels of beta-amyloid((1-42)) and tau in patients with retinal diseases. Jpn J Ophthalmol (2005) 49(2):106-8. doi:10.1007/s10384004-0156-x

48. Sipe JD, Cohen AS. Review: history of the amyloid fibril. J Struct Biol (2000) 130(2-3):88-98. doi:10.1006/jsbi.2000.4221

49. Marcinkiewicz M, Seidah NG. Coordinated expression of beta-amyloid precursor protein and the putative beta-secretase BACE and alpha-secretase ADAM10 in mouse and human brain. J Neurochem (2000) 75(5):2133-43. doi:10.1046/j.1471-4159.2000.0752133.x

50. Fukuchi K, Kamino K, Deeb SS, Smith AC, Dang T, Martin GM. Overexpression of amyloid precursor protein alters its normal processing and is associated with neurotoxicity. Biochem Biophys Res Commun (1992) 182(1):165-73. doi:10.1016/S0006-291X(05)80126-3

51. Hoh Kam J, Lenassi E, Jeffery G. Viewing ageing eyes: diverse sites of amyloid Beta accumulation in the ageing mouse retina and the up-regulation of macrophages. PLoS One (2010) 5(10):e13127. doi:10.1371/journal.pone. 0013127

52. Glotin AL, Debacq-Chainiaux F, Brossas JY, Faussat AM, Treton J, Zubielewicz A, et al. Prematurely senescent ARPE-19 cells display features of age-related macular degeneration. Free Radic Biol Med (2008) 44(7):1348-61. doi:10.1016/j.freeradbiomed.2007.12.023

53. Curcio CA, Millican CL, Allen KA, Kalina RE. Aging of the human photoreceptor mosaic: evidence for selective vulnerability of rods in central retina. Invest Ophthalmol Vis Sci (1993) 34(12):3278-96.

54. El-Agnaf OM, Mahil DS, Patel BP, Austen BM. Oligomerization and toxicity of beta-amyloid-42 implicated in Alzheimer's disease. Biochem Biophys Res Commun (2000) 273(3):1003-7. doi:10.1006/bbrc.2000.3051

55. Hardy JA, Higgins GA. Alzheimer's disease: the amyloid cascade hypothesis. Science (1992) 256(5054):184-5. doi:10.1126/science.1566067

56. Selkoe DJ, Hardy J. The amyloid hypothesis of Alzheimer's disease at 25 years. EMBO Mol Med (2016) 8(6):595-608. doi:10.15252/emmm.201606210

57. Haass C, Selkoe DJ. Soluble protein oligomers in neurodegeneration: lessons from the Alzheimer's amyloid beta-peptide. Nat Rev Mol Cell Biol (2007) 8(2):101-12. doi:10.1038/nrm2101

58. Mc Donald JM, Savva GM, Brayne C, Welzel AT, Forster G, Shankar GM, et al. The presence of sodium dodecyl sulphate-stable Abeta dimers is strongly associated with Alzheimer-type dementia. Brain (2010) 133(Pt 5):1328-41. doi:10.1093/brain/awq065

59. Ono K, Condron MM, Teplow DB. Structure-neurotoxicity relationships of amyloid beta-protein oligomers. Proc Natl Acad Sci U S A (2009) 106(35):14745-50. doi:10.1073/pnas.0905127106

60. Lesne S, Koh MT, Kotilinek L, Kayed R, Glabe CG, Yang A, et al. A specific amyloid-beta protein assembly in the brain impairs memory. Nature (2006) 440(7082):352-7. doi:10.1038/nature04533
61. Brouillette J. The effects of soluble A $\beta$ oligomers on neurodegeneration in Alzheimer's disease. Curr Pharm Des (2014) 20(15):2506-19. doi:10.2174/ 13816128113199990498

62. Wirths O, Multhaup G, Czech C, Blanchard V, Moussaoui S, Tremp G, et al. Intraneuronal Abeta accumulation precedes plaque formation in beta-amyloid precursor protein and presenilin-1 double-transgenic mice. Neurosci Lett (2001) 306(1-2):116-20. doi:10.1016/S0304-3940(01)01876-6

63. Gomez-Ramos P, Asuncion Moran M. Ultrastructural localization of intraneuronal Abeta-peptide in Alzheimer disease brains. J Alzheimers Dis (2007) 11(1):53-9.

64. Shankar GM, Li S, Mehta TH, Garcia-Munoz A, Shepardson NE, Smith I, et al. Amyloid-beta protein dimers isolated directly from Alzheimer's brains impair synaptic plasticity and memory. Nat Med (2008) 14(8):837-42. doi: $10.1038 / \mathrm{nm} 1782$

65. Minter MR, Taylor JM, Crack PJ. The contribution of neuroinflammation to amyloid toxicity in Alzheimer's disease. J Neurochem (2016) 136(3):457-74. doi:10.1111/jnc.13411

66. Van Nostrand WE. The influence of the amyloid ss-protein and its precursor in modulating cerebral hemostasis. Biochim Biophys Acta (2016) 1862(5):1018-26. doi:10.1016/j.bbadis.2015.10.020

67. Palop JJ, Mucke L. Amyloid-beta-induced neuronal dysfunction in Alzheimer's disease: from synapses toward neural networks. Nat Neurosci (2010) 13(7):812-8. doi:10.1038/nn.2583

68. Hsia AY, Masliah E, McConlogue L, Yu GQ, Tatsuno G, Hu K, et al. Plaqueindependent disruption of neural circuits in Alzheimer's disease mouse models. Proc Natl Acad Sci U S A (1999) 96(6):3228-33. doi:10.1073/ pnas.96.6.3228

69. Walsh DM, Klyubin I, Fadeeva JV, Cullen WK, Anwyl R, Wolfe MS, et al. Naturally secreted oligomers of amyloid beta protein potently inhibit hippocampal long-term potentiation in vivo. Nature (2002) 416(6880):535-9. doi:10.1038/416535a

70. Hsieh H, Boehm J, Sato C, Iwatsubo T, Tomita T, Sisodia S, et al. AMPAR removal underlies Abeta-induced synaptic depression and dendritic spine loss. Neuron (2006) 52(5):831-43. doi:10.1016/j.neuron.2006.10.035

71. Shankar GM, Bloodgood BL, Townsend M, Walsh DM, Selkoe DJ, Sabatini BL. Natural oligomers of the Alzheimer amyloid-beta protein induce reversible synapse loss by modulating an NMDA-type glutamate receptordependent signaling pathway. J Neurosci (2007) 27(11):2866-75. doi:10.1523/ JNEUROSCI.4970-06.2007

72. Liu SJ, Gasperini R, Foa L, Small DH. Amyloid-beta decreases cell-surface AMPA receptors by increasing intracellular calcium and phosphorylation of GluR2. J Alzheimers Dis (2010) 21(2):655-66. doi:10.3233/JAD2010-091654

73. Snyder EM, Nong Y, Almeida CG, Paul S, Moran T, Choi EY, et al. Regulation of NMDA receptor trafficking by amyloid-beta. Nat Neurosci (2005) 8(8):1051-8. doi:10.1038/nn1503

74. Puzzo D, Privitera L, Leznik E, Fa M, Staniszewski A, Palmeri A, et al. Picomolar amyloid-beta positively modulates synaptic plasticity and memory in hippocampus. J Neurosci (2008) 28(53):14537-45. doi:10.1523/ JNEUROSCI.2692-08.2008

75. Vezzani A, Granata T. Brain inflammation in epilepsy: experimental and clinical evidence. Epilepsia (2005) 46(11):1724-43. doi:10.1111/j.15281167.2005.00298.x

76. Minkeviciene R, Rheims S, Dobszay MB, Zilberter M, Hartikainen J, Fulop L, et al. Amyloid beta-induced neuronal hyperexcitability triggers progressive epilepsy. J Neurosci (2009) 29(11):3453-62. doi:10.1523/ JNEUROSCI.5215-08.2009

77. Tamagnini F, Scullion S, Brown JT, Randall AD. Intrinsic excitability changes induced by acute treatment of hippocampal CA1 pyramidal neurons with exogenous amyloid beta peptide. Hippocampus (2015) 25(7):786-97. doi:10.1002/hipo.22403

78. Walsh DT, Bresciani L, Saunders D, Manca MF, Jen A, Gentleman SM, et al. Amyloid beta peptide causes chronic glial cell activation and neuro-degeneration after intravitreal injection. Neuropathol Appl Neurobiol (2005) 31(5):491-502. doi:10.1111/j.1365-2990.2005.00666.x

79. Aruoma OI, Jen SS, Watts HR, George J, Gentleman SM, Anderson PJ, et al. Acute and chronic effects of intravitreally injected beta-amyloid on the neurotransmitter system in the retina. Toxicology (2009) 256(1-2):92-100. doi:10.1016/j.tox.2008.11.007 
80. Kumar A, Singh A. A review on mitochondrial restorative mechanism of antioxidants in Alzheimer's disease and other neurological conditions. Front Pharmacol (2015) 6:206. doi:10.3389/fphar.2015.00206

81. Ohyagi Y, Asahara H, Chui DH, Tsuruta Y, Sakae N, Miyoshi K, et al. Intracellular Abeta42 activates p53 promoter: a pathway to neurodegeneration in Alzheimer's disease. FASEB J (2005) 19(2):255-7. doi:10.1096/ fj.04-2637fje

82. Suo Z, Cox AA, Bartelli N, Rasul I, Festoff BW, Premont RT, et al. GRK5 deficiency leads to early Alzheimer-like pathology and working memory impairment. Neurobiol Aging (2007) 28(12):1873-88. doi:10.1016/j. neurobiolaging.2006.08.013

83. Sonkusare SK, Kaul CL, Ramarao P. Dementia of Alzheimer's disease and other neurodegenerative disorders - memantine, a new hope. Pharmacol Res (2005) 51(1):1-17. doi:10.1016/j.phrs.2004.05.005

84. Huang HM, Zhang $\mathrm{H}, \mathrm{Xu} \mathrm{H}$, Gibson GE. Inhibition of the alpha-ketoglutarate dehydrogenase complex alters mitochondrial function and cellular calcium regulation. Biochim Biophys Acta (2003) 1637(1):119-26. doi:10.1016/ S0925-4439(02)00222-3

85. Bubber P, Haroutunian V, Fisch G, Blass JP, Gibson GE. Mitochondrial abnormalities in Alzheimer brain: mechanistic implications. Ann Neurol (2005) 57(5):695-703. doi:10.1002/ana.20474

86. Rhein V, Song X, Wiesner A, Ittner LM, Baysang G, Meier F, et al. Amyloidbeta and tau synergistically impair the oxidative phosphorylation system in triple transgenic Alzheimer's disease mice. Proc Natl Acad Sci U S A (2009) 106(47):20057-62. doi:10.1073/pnas.0905529106

87. Swerdlow RH, Burns JM, Khan SM. The Alzheimer's disease mitochondrial cascade hypothesis. J Alzheimers Dis (2010) 20(Suppl 2):S265-79. doi:10.3233/JAD-2010-100339

88. Lustbader JW, Cirilli M, Lin C, Xu HW, Takuma K, Wang N, et al. ABAD directly links Abeta to mitochondrial toxicity in Alzheimer's disease. Science (2004) 304(5669):448-52. doi:10.1126/science.1091230

89. Calkins MJ, Reddy PH. Amyloid beta impairs mitochondrial anterograde transport and degenerates synapses in Alzheimer's disease neurons. Biochim Biophys Acta (2011) 1812(4):507-13. doi:10.1016/j.bbadis.2011. 01.007

90. Manczak M, Calkins MJ, Reddy PH. Impaired mitochondrial dynamics and abnormal interaction of amyloid beta with mitochondrial protein Drp1 in neurons from patients with Alzheimer's disease: implications for neuronal damage. Hum Mol Genet (2011) 20(13):2495-509. doi:10.1093/ hmg/ddr139

91. Bruban J, Glotin AL, Dinet V, Chalour N, Sennlaub F, Jonet L, et al. Amyloid-beta(1-42) alters structure and function of retinal pigmented epithelial cells. Aging Cell (2009) 8(2):162-77. doi:10.1111/j.1474-9726.2009. 00456.x

92. De Strooper B, Karran E. The cellular phase of Alzheimer's disease. Cell (2016) 164(4):603-15. doi:10.1016/j.cell.2015.12.056

93. Lian H, Yang L, Cole A, Sun L, Chiang AC, Fowler SW, et al. NFkappaBactivated astroglial release of complement C3 compromises neuronal morphology and function associated with Alzheimer's disease. Neuron (2015) 85(1):101-15. doi:10.1016/j.neuron.2014.11.018

94. Lian H, Litvinchuk A, Chiang AC, Aithmitti N, Jankowsky JL, Zheng H. Astrocyte-microglia cross talk through complement activation modulates amyloid pathology in mouse models of Alzheimer's disease. J Neurosci (2016) 36(2):577-89. doi:10.1523/JNEUROSCI.2117-15.2016

95. Osborn LM, Kamphuis W, Wadman WJ, Hol EM. Astrogliosis: an integral player in the pathogenesis of Alzheimer's disease. Prog Neurobiol (2016) S0301-0082(15):30021-6. doi:10.1016/j.pneurobio.2016.01.001

96. Pihlaja R, Koistinaho J, Kauppinen R, Sandholm J, Tanila H, Koistinaho M. Multiple cellular and molecular mechanisms are involved in human Abeta clearance by transplanted adult astrocytes. Glia (2011) 59(11):1643-57. doi:10.1002/glia.21212

97. Saido T, Leissring MA. Proteolytic degradation of amyloid beta-protein. Cold Spring Harb Perspect Med (2012) 2(6):a006379. doi:10.1101/cshperspect. a006379

98. Kettenmann H, Hanisch UK, Noda M, Verkhratsky A. Physiology of microglia. Physiol Rev (2011) 91(2):461-553. doi:10.1152/physrev.00011.2010

99. Ji K, Akgul G, Wollmuth LP, Tsirka SE. Microglia actively regulate the number of functional synapses. PLoS One (2013) 8(2):e56293. doi:10.1371/ journal.pone.0056293
100. Heneka MT, Carson MJ, El Khoury J, Landreth GE, Brosseron F, Feinstein DL, et al. Neuroinflammation in Alzheimer's disease. Lancet Neurol (2015) 14(4):388-405. doi:10.1016/S1474-4422(15)70016-5

101. El Khoury JB, Moore KJ, Means TK, Leung J, Terada K, Toft M, et al. CD36 mediates the innate host response to beta-amyloid. J Exp Med (2003) 197(12):1657-66. doi:10.1084/jem.20021546

102. Stewart CR, Stuart LM, Wilkinson K, van Gils JM, Deng J, Halle A, et al. CD36 ligands promote sterile inflammation through assembly of a tolllike receptor 4 and 6 heterodimer. Nat Immunol (2010) 11(2):155-61. doi:10.1038/ni.1836

103. Liu Y, Walter S, Stagi M, Cherny D, Letiembre M, Schulz-Schaeffer W, et al. LPS receptor (CD14): a receptor for phagocytosis of Alzheimer's amyloid peptide. Brain (2005) 128(Pt 8):1778-89. doi:10.1093/brain/awh531

104. Lee CY, Landreth GE. The role of microglia in amyloid clearance from the AD brain. J Neural Transm (Vienna) (2010) 117(8):949-60. doi:10.1007/ s00702-010-0433-4

105. Lue LF, Rydel R, Brigham EF, Yang LB, Hampel H, Murphy GM Jr, et al. Inflammatory repertoire of Alzheimer's disease and nondemented elderly microglia in vitro. Glia (2001) 35(1):72-9. doi:10.1002/glia.1072

106. Patel NS, Paris D, Mathura V, Quadros AN, Crawford FC, Mullan MJ. Inflammatory cytokine levels correlate with amyloid load in transgenic mouse models of Alzheimer's disease. J Neuroinflammation (2005) 2(1):9. doi:10.1186/1742-2094-2-9

107. Liao YF, Wang BJ, Cheng HT, Kuo LH, Wolfe MS. Tumor necrosis factoralpha, interleukin-1beta, and interferon-gamma stimulate gamma-secretasemediated cleavage of amyloid precursor protein through a JNK-dependent MAPK pathway. JBiol Chem (2004) 279(47):49523-32. doi:10.1074/ jbc.M402034200

108. Yamamoto M, Kiyota T, Horiba M, Buescher JL, Walsh SM, Gendelman $\mathrm{HE}$, et al. Interferon-gamma and tumor necrosis factor-alpha regulate amyloid-beta plaque deposition and beta-secretase expression in Swedish mutant APP transgenic mice. Am JPathol (2007) 170(2):680-92. doi:10.2353/ ajpath.2007.060378

109. He P, Zhong Z, Lindholm K, Berning L, Lee W, Lemere C, et al. Deletion of tumor necrosis factor death receptor inhibits amyloid beta generation and prevents learning and memory deficits in Alzheimer's mice. J Cell Biol (2007) 178(5):829-41. doi:10.1083/jcb.200705042

110. Chen ST, Gentleman SM, Garey LJ, Jen LS. Distribution of beta-amyloid precursor and B-cell lymphoma protooncogene proteins in the rat retina after optic nerve transection or vascular lesion. J Neuropathol Exp Neurol (1996) 55(10):1073-82. doi:10.1097/00005072-199655100-00007

111. Cunvong K, Huffmire D, Ethell DW, Cameron DJ. Amyloid-beta increases capillary bed density in the adult zebrafish retina. Invest Ophthalmol Vis Sci (2013) 54(2):1516-21. doi:10.1167/iovs.12-10821

112. Cai J, Qi X, Kociok N, Skosyrski S, Emilio A, Ruan Q, et al. $\beta$-Secretase (BACE1) inhibition causes retinal pathology by vascular dysregulation and accumulation of age pigment. EMBO Mol Med (2012) 4(9):980-91. doi:10.1002/emmm.201101084

113. Sun LH, Ban T, Liu CD, Chen QX, Wang X, Yan ML, et al. Activation of Cdk5/p25 and tau phosphorylation following chronic brain hypoperfusion in rats involves microRNA-195 down-regulation. J Neurochem (2015) 134(6):1139-51. doi:10.1111/jnc.13212

114. Cheng X, He P, Yao H, Dong Q, Li R, Shen Y. Occludin deficiency with BACE1 elevation in cerebral amyloid angiopathy. Neurology (2014) 82(19):1707-15. doi:10.1212/WNL.0000000000000403

115. Koizumi K, Wang G, Park L. Endothelial dysfunction and amyloid-beta-induced neurovascular alterations. Cell Mol Neurobiol (2016) 36(2):155-65. doi:10.1007/s10571-015-0256-9

116. Kook SY, Seok Hong H, Moon M, Mook-Jung I. Disruption of blood-brain barrier in Alzheimer disease pathogenesis. Tissue Barriers (2013) 1(2):e23993. doi: $10.4161 /$ tisb. 23993

117. Caceres A, Kosik KS. Inhibition of neurite polarity by tau antisense oligonucleotides in primary cerebellar neurons. Nature (1990) 343(6257):461-3. doi:10.1038/343461a0

118. King ME, Kan HM, Baas PW, Erisir A, Glabe CG, Bloom GS. Tau-dependent microtubule disassembly initiated by prefibrillar beta-amyloid. J Cell Biol (2006) 175(4):541-6. doi:10.1083/jcb.200605187

119. Khan SS, Bloom GS. Tau: the center of a signaling nexus in Alzheimer's disease. Front Neurosci (2016) 10:31. doi:10.3389/fnins.2016.00031 
120. Brion JP. The role of neurofibrillary tangles in Alzheimer disease. Acta Neurol Belg (1998) 98(2):165-74.

121. Sorrentino G, Bonavita V. Neurodegeneration and Alzheimer's disease: the lesson from tauopathies. Neurol Sci (2007) 28(2):63-71. doi:10.1007/ s10072-007-0789-x

122. Dineley KT, Bell KA, Bui D, Sweatt JD. beta-Amyloid peptide activates alpha 7 nicotinic acetylcholine receptors expressed in Xenopus oocytes. J Biol Chem (2002) 277(28):25056-61. doi:10.1074/jbc.M200066200

123. Li S, Hong S, Shepardson NE, Walsh DM, Shankar GM, Selkoe D. Soluble oligomers of amyloid beta protein facilitate hippocampal long-term depression by disrupting neuronal glutamate uptake. Neuron (2009) 62(6):788-801. doi:10.1016/j.neuron.2009.05.012

124. Palop JJ, Chin J, Roberson ED, Wang J, Thwin MT, Bien-Ly N, et al. Aberrant excitatory neuronal activity and compensatory remodeling of inhibitory hippocampal circuits in mouse models of Alzheimer's disease. Neuron (2007) 55(5):697-711. doi:10.1016/j.neuron.2007.07.025

125. Anandatheerthavarada HK, Biswas G, Robin MA, Avadhani NG. Mitochondrial targeting and a novel transmembrane arrest of Alzheimer's amyloid precursor protein impairs mitochondrial function in neuronal cells. J Cell Biol (2003) 161(1):41-54. doi:10.1083/jcb.200207030

126. Pinho CM, Teixeira PF, Glaser E. Mitochondrial import and degradation of amyloid-beta peptide. Biochim Biophys Acta (2014) 1837(7):1069-74. doi:10.1016/j.bbabio.2014.02.007

127. Chen JX, Yan SD. Amyloid-beta-induced mitochondrial dysfunction. J Alzheimers Dis (2007) 12(2):177-84.

128. Picone P, Nuzzo D, Caruana L, Scafidi V, Di Carlo M. Mitochondrial dysfunction: different routes to Alzheimer's disease therapy. Oxid Med Cell Longev (2014) 2014:780179. doi:10.1155/2014/780179

129. Ren H, Fu K, Wang D, Mu C, Wang G. Oxidized DJ-1 interacts with the mitochondrial protein BCL-XL. J Biol Chem (2011) 286(40):35308-17. doi:10.1074/jbc.M110.207134

130. Moreira PI, Carvalho C, Zhu X, Smith MA, Perry G. Mitochondrial dysfunction is a trigger of Alzheimer's disease pathophysiology. Biochim Biophys Acta (2010) 1802(1):2-10. doi:10.1016/j.bbadis.2009.10.006

131. Beach TG, Walker R, McGeer EG. Patterns of gliosis in Alzheimer's disease and aging cerebrum. Glia (1989) 2(6):420-36. doi:10.1002/glia. 440020605

132. Delacourte A. General and dramatic glial reaction in Alzheimer brains. Neurology (1990) 40(1):33-7. doi:10.1212/WNL.40.1.33

133. Arends YM, Duyckaerts C, Rozemuller JM, Eikelenboom P, Hauw JJ. Microglia, amyloid and dementia in Alzheimer disease. A correlative study. Neurobiol Aging (2000) 21(1):39-47. doi:10.1016/S0197-4580(00)00094-4

134. Cagnin A, Brooks DJ, Kennedy AM, Gunn RN, Myers R, Turkheimer FE, et al. In-vivo measurement of activated microglia in dementia. Lancet (2001) 358(9280):461-7. doi:10.1016/S0140-6736(01)05625-2

135. Jimenez S, Baglietto-Vargas D, Caballero C, Moreno-Gonzalez I, Torres $\mathrm{M}$, Sanchez-Varo R, et al. Inflammatory response in the hippocampus of PS1M146L/APP751SL mouse model of Alzheimer's disease: age-dependent switch in the microglial phenotype from alternative to classic. J Neurosci (2008) 28(45):11650-61. doi:10.1523/JNEUROSCI.3024-08.2008

136. Couturier J, Paccalin M, Morel M, Terro F, Milin S, Pontcharraud R, et al. Prevention of the beta-amyloid peptide-induced inflammatory process by inhibition of double-stranded RNA-dependent protein kinase in primary murine mixed co-cultures. J Neuroinflammation (2011) 8:72. doi:10.1186/1742-2094-8-72

137. Zhang W, Bai M, Xi Y, Hao J, Zhang Z, Su C, et al. Multiple inflammatory pathways are involved in the development and progression of cognitive deficits in APPswe/PS1dE9 mice. Neurobiol Aging (2012) 33(11):2661-77. doi:10.1016/j.neurobiolaging.2011.12.023

138. Apelt J, Schliebs R. Beta-amyloid-induced glial expression of both pro- and anti-inflammatory cytokines in cerebral cortex of aged transgenic Tg2576 mice with Alzheimer plaque pathology. Brain Res (2001) 894(1):21-30. doi:10.1016/S0006-8993(00)03176-0

139. Janelsins MC, Mastrangelo MA, Oddo S, LaFerla FM, Federoff HJ, Bowers WJ. Early correlation of microglial activation with enhanced tumor necrosis factor-alpha and monocyte chemoattractant protein-1 expression specifically within the entorhinal cortex of triple transgenic Alzheimer's disease mice. JNeuroinflammation (2005) 2:23. doi:10.1186/17422094-2-23
140. Ma K, Mount HT, McLaurin J. Region-specific distribution of betaamyloid peptide and cytokine expression in TgCRND8 mice. Neurosci Lett (2011) 492(1):5-10. doi:10.1016/j.neulet.2011.01.035

141. Fernandez-Perez EJ, Peters C, Aguayo LG. Membrane damage induced by amyloid beta and a potential link with neuroinflammation. Curr Pharm Des (2016) 22(10):1295-304. doi:10.2174/138161282210160304111702

142. Wright AL, Zinn R, Hohensinn B, Konen LM, Beynon SB, Tan RP, et al. Neuroinflammation and neuronal loss precede Abeta plaque deposition in the hAPP-J20 mouse model of Alzheimer's disease. PLoS One (2013) 8(4):e59586. doi:10.1371/journal.pone.0059586

143. Cavanagh C, Colby-Milley J, Bouvier D, Farso M, Chabot JG, Quirion R, et al. $\beta$ CTF-correlated burst of hippocampal TNFalpha occurs at a very early, pre-plaque stage in the TgCRND8 mouse model of Alzheimer's disease. J Alzheimers Dis (2013) 36(2):233-8. doi:10.3233/JAD-122131

144. Hainsworth AH, Oommen AT, Bridges LR. Endothelial cells and human cerebral small vessel disease. Brain Pathol (2015) 25(1):44-50. doi:10.1111/ bpa. 12224

145. Yamada M. Cerebral amyloid angiopathy: emerging concepts. J Stroke (2015) 17(1):17-30. doi:10.5853/jos.2015.17.1.17

146. Vinters HV. Emerging concepts in Alzheimer's disease. Annu Rev Pathol (2015) 10:291-319. doi:10.1146/annurev-pathol-020712-163927

147. Lai AY, Dorr A, Thomason LA, Koletar MM, Sled JG, Stefanovic B, et al. Venular degeneration leads to vascular dysfunction in a transgenic model of Alzheimer's disease. Brain (2015) 138(Pt 4):1046-58. doi:10.1093/ brain/awv023

148. Lo P, Crouzet C, Vasilevko V, Choi B. Visualization of microbleeds with optical histology in mouse model of cerebral amyloid angiopathy. Microvasc Res (2016) 105:109-13. doi:10.1016/j.mvr.2016.02.002

149. Ning A, Cui J, To E, Ashe KH, Matsubara J. Amyloid-beta deposits lead to retinal degeneration in a mouse model of Alzheimer disease. Invest Ophthalmol Vis Sci (2008) 49(11):5136-43. doi:10.1167/iovs.08-1849

150. Danesh-Meyer HV, Birch H, Ku JY, Carroll S, Gamble G. Reduction of optic nerve fibers in patients with Alzheimer disease identified by laser imaging. Neurology (2006) 67(10):1852-4. doi:10.1212/01.wnl.0000244490.07925.8b

151. Paquet C, Boissonnot M, Roger F, Dighiero P, Gil R, Hugon J. Abnormal retinal thickness in patients with mild cognitive impairment and Alzheimer's disease. Neurosci Lett (2007) 420(2):97-9. doi:10.1016/j. neulet.2007.02.090

152. Blanks JC, Hinton DR, Sadun AA, Miller CA. Retinal ganglion cell degeneration in Alzheimer's disease. Brain Res (1989) 501(2):364-72. doi:10.1016/0006-8993(89)90653-7

153. Sadun AA, Bassi CJ. Optic nerve damage in Alzheimer's disease. Ophthalmology (1990) 97(1):9-17. doi:10.1016/S0161-6420(90)32621-0

154. Dutescu RM, Li QX, Crowston J, Masters CL, Baird PN, Culvenor JG. Amyloid precursor protein processing and retinal pathology in mouse models of Alzheimer's disease. Graefes Arch Clin Exp Ophthalmol (2009) 247(9):1213-21. doi:10.1007/s00417-009-1060-3

155. Perez SE, Lumayag S, Kovacs B, Mufson EJ, Xu S. Beta-amyloid deposition and functional impairment in the retina of the APPswe/PS1DeltaE9 transgenic mouse model of Alzheimer's disease. Invest Ophthalmol Vis Sci (2009) 50(2):793-800. doi:10.1167/iovs.08-2384

156. Parnell M, Guo L, Abdi M, Cordeiro MF. Ocular manifestations of Alzheimer's disease in animal models. Int JAlzheimers Dis (2012) 2012:786494. doi: $10.1155 / 2012 / 786494$

157. Parisi V, Restuccia R, Fattapposta F, Mina C, Bucci MG, Pierelli F. Morphological and functional retinal impairment in Alzheimer's disease patients. Clin Neurophysiol (2001) 112(10):1860-7. doi:10.1016/ S1388-2457(01)00620-4

158. Bruban J, Maoui A, Chalour N, An N, Jonet L, Feumi C, et al. CCR2/ CCL2-mediated inflammation protects photoreceptor cells from amyloidbeta-induced apoptosis. Neurobiol Dis (2011) 42(1):55-72. doi:10.1016/j. nbd.2011.01.004

159. Dinet V, Bruban J, Chalour N, Maoui A, An N, Jonet L, et al. Distinct effects of inflammation on gliosis, osmohomeostasis, and vascular integrity during amyloid beta-induced retinal degeneration. Aging Cell (2012) 11(4):683-93. doi:10.1111/j.1474-9726.2012.00834.x

160. Walsh DT, Montero RM, Bresciani LG, Jen AY, Leclercq PD, Saunders D, et al. Amyloid-beta peptide is toxic to neurons in vivo via indirect mechanisms. Neurobiol Dis (2002) 10(1):20-7. doi:10.1006/nbdi.2002.0485 
161. Solodkin A, Veldhuizen SD, Van Hoesen GW. Contingent vulnerability of entorhinal parvalbumin-containing neurons in Alzheimer's disease. J Neurosci (1996) 16(10):3311-21.

162. Takahashi H, Brasnjevic I, Rutten BP, Van Der Kolk N, Perl DP, Bouras C, et al. Hippocampal interneuron loss in an APP/PS1 double mutant mouse and in Alzheimer's disease. Brain Struct Funct (2010) 214(2-3):145-60. doi:10.1007/s00429-010-0242-4

163. Albuquerque MS, Mahar I, Davoli MA, Chabot JG, Mechawar N, Quirion $\mathrm{R}$, et al. Regional and sub-regional differences in hippocampal GABAergic neuronal vulnerability in the TgCRND8 mouse model of Alzheimer's disease. Front Aging Neurosci (2015) 7:30. doi:10.3389/fnagi.2015.00030

164. Berisha F, Feke GT, Trempe CL, McMeel JW, Schepens CL. Retinal abnormalities in early Alzheimer's disease. Invest Ophthalmol Vis Sci (2007) 48(5):2285-9. doi:10.1167/iovs.06-1029

165. Williams MA, McGowan AJ, Cardwell CR, Cheung CY, Craig D, Passmore P, et al. Retinal microvascular network attenuation in Alzheimer's disease. Alzheimers Dement (Amst) (2015) 1(2):229-35. doi:10.1016/j.dadm. 2015.04.001

166. Feke GT, Hyman BT, Stern RA, Pasquale LR. Retinal blood flow in mild cognitive impairment and Alzheimer's disease. Alzheimers Dement (Amst) (2015) 1(2):144-51. doi:10.1016/j.dadm.2015.01.004

167. Klein R, Peto T, Bird A, Vannewkirk MR. The epidemiology of age-related macular degeneration. Am J Ophthalmol (2004) 137(3):486-95. doi:10.1016/j. ajo.2003.11.069

168. McLeod DS, Taomoto M, Otsuji T, Green WR, Sunness JS, Lutty GA. Quantifying changes in RPE and choroidal vasculature in eyes with agerelated macular degeneration. Invest Ophthalmol Vis Sci (2002) 43(6):1986-93.

169. Zarbin MA. Current concepts in the pathogenesis of age-related macular degeneration. Arch Ophthalmol (2004) 122(4):598-614. doi:10.1001/ archopht.122.4.598

170. Sivak JM. The aging eye: common degenerative mechanisms between the Alzheimer's brain and retinal disease. Invest Ophthalmol Vis Sci (2013) 54(1):871-80. doi:10.1167/iovs.12-10827

171. de Jong PT. Age-related macular degeneration. N Engl JMed (2006) 355(14):1474-85. doi:10.1056/NEJMra662326

172. Luibl V, Isas JM, Kayed R, Glabe CG, Langen R, Chen J. Drusen deposits associated with aging and age-related macular degeneration contain nonfibrillar amyloid oligomers. J Clin Invest (2006) 116(2):378-85. doi:10.1172/ JCI25843

173. Sparrow JR. Bisretinoids of RPE lipofuscin: trigger for complement activation in age-related macular degeneration. Adv Exp Med Biol (2010) 703:63-74. doi:10.1007/978-1-4419-5635-4_5

174. Johnson LV, Leitner WP, Rivest AJ, Staples MK, Radeke MJ, Anderson DH. The Alzheimer's A beta-peptide is deposited at sites of complement activation in pathologic deposits associated with aging and age-related macular degeneration. Proc Natl Acad Sci U S A (2002) 99(18):11830-5. doi:10.1073/ pnas.192203399

175. Dentchev T, Milam AH, Lee VM, Trojanowski JQ, Dunaief JL. Amyloid-beta is found in drusen from some age-related macular degeneration retinas, but not in drusen from normal retinas. Mol Vis (2003) 9:184-90.

176. Anderson DH, Talaga KC, Rivest AJ, Barron E, Hageman GS, Johnson LV. Characterization of beta amyloid assemblies in drusen: the deposits associated with aging and age-related macular degeneration. Exp Eye Res (2004) 78(2):243-56. doi:10.1016/j.exer.2003.10.011

177. Glabe CG. Common mechanisms of amyloid oligomer pathogenesis in degenerative disease. Neurobiol Aging (2006) 27(4):570-5. doi:10.1016/j. neurobiolaging.2005.04.017

178. Johnson PT, Lewis GP, Talaga KC, Brown MN, Kappel PJ, Fisher SK, et al. Drusen-associated degeneration in the retina. Invest Ophthalmol Vis Sci (2003) 44(10):4481-8. doi:10.1167/iovs.03-0436

179. Edwards AO, Ritter R III, Abel KJ, Manning A, Panhuysen C, Farrer LA. Complement factor $\mathrm{H}$ polymorphism and age-related macular degeneration. Science (2005) 308(5720):421-4. doi:10.1126/science.1110189

180. Hageman GS, Anderson DH, Johnson LV, Hancox LS, Taiber AJ, Hardisty LI, et al. A common haplotype in the complement regulatory gene factor $\mathrm{H}(\mathrm{HF} 1 / \mathrm{CFH})$ predisposes individuals to age-related macular degeneration. Proc Natl Acad Sci U S A (2005) 102(20):7227-32. doi:10.1073/pnas. 0501536102
181. Haines JL, Hauser MA, Schmidt S, Scott WK, Olson LM, Gallins P, et al. Complement factor $\mathrm{H}$ variant increases the risk of age-related macular degeneration. Science (2005) 308(5720):419-21. doi:10.1126/science. 1110359

182. Despriet DD, Klaver CC, Witteman JC, Bergen AA, Kardys I, de Maat MP, et al. Complement factor $\mathrm{H}$ polymorphism, complement activators, and risk of age-related macular degeneration. JAMA (2006) 296(3):301-9. doi:10.1001/jama.296.3.301

183. Coffey PJ, Gias C, McDermott CJ, Lundh P, Pickering MC, Sethi C, et al. Complement factor $\mathrm{H}$ deficiency in aged mice causes retinal abnormalities and visual dysfunction. Proc Natl Acad Sci U S A (2007) 104(42):16651-6. doi:10.1073/pnas.0705079104

184. Zhang DF, Li J, Wu H, Cui Y, Bi R, Zhou HJ, et al. CFH variants affect structural and functional brain changes and genetic risk of Alzheimer's disease. Neuropsychopharmacology (2016) 41(4):1034-45. doi:10.1038/ npp.2015.232

185. Zetterberg M, Landgren S, Andersson ME, Palmer MS, Gustafson DR, Skoog I, et al. Association of complement factor $\mathrm{H} \mathrm{Y} 402 \mathrm{H}$ gene polymorphism with Alzheimer's disease. Am J Med Genet B Neuropsychiatr Genet (2008) 147B(6):720-6. doi:10.1002/ajmg.b.30668

186. Sullivan RK, Woldemussie E, Pow DV. Dendritic and synaptic plasticity of neurons in the human age-related macular degeneration retina. Invest Ophthalmol Vis Sci (2007) 48(6):2782-91. doi:10.1167/iovs.06-1283

187. Yoshida T, Ohno-Matsui K, Ichinose S, Sato T, Iwata N, Saido TC, et al. The potential role of amyloid beta in the pathogenesis of age-related macular degeneration. J Clin Invest (2005) 115(10):2793-800. doi:10.1172/JCI24635

188. Patel M, Chan CC. Immunopathological aspects of age-related macular degeneration. Semin Immunopathol (2008) 30(2):97-110. doi:10.1007/ s00281-008-0112-9

189. Nozaki M, Raisler BJ, Sakurai E, Sarma JV, Barnum SR, Lambris JD, et al. Drusen complement components C3a and C5a promote choroidal neovascularization. Proc Natl Acad Sci U S A (2006) 103(7):2328-33. doi:10.1073/ pnas.0408835103

190. Heneka MT, O'Banion MK. Inflammatory processes in Alzheimer's disease. J Neuroimmunol (2007) 184(1-2):69-91. doi:10.1016/j.jneuroim. 2006.11.017

191. Biron KE, Dickstein DL, Gopaul R, Jefferies WA. Amyloid triggers extensive cerebral angiogenesis causing blood brain barrier permeability and hypervascularity in Alzheimer's disease. PLoS One (2011) 6(8):e23789. doi:10.1371/ journal.pone.0023789

192. Chin YC, Wong TY, Cheung CM, Cheung CY, Zheng Y, Mitchell P, et al. Retinal vascular caliber and age-related macular degeneration in an Indian population from Singapore. Ophthalmic Epidemiol (2014) 21(4):224-9. doi:10.3109/09286586.2014.926941

193. Liew G, Kaushik S, Rochtchina E, Tan AG, Mitchell P, Wang JJ. Retinal vessel signs and 10-year incident age-related maculopathy: the Blue Mountains Eye Study. Ophthalmology (2006) 113(9):1481-7. doi:10.1016/j. ophtha.2006.03.051

194. Yucel YH, Zhang Q, Gupta N, Kaufman PL, Weinreb RN. Loss of neurons in magnocellular and parvocellular layers of the lateral geniculate nucleus in glaucoma. Arch Ophthalmol (2000) 118(3):378-84. doi:10.1001/ archopht.118.3.378

195. Yucel YH, Zhang Q, Weinreb RN, Kaufman PL, Gupta N. Effects of retinal ganglion cell loss on magno-, parvo-, koniocellular pathways in the lateral geniculate nucleus and visual cortex in glaucoma. Prog Retin Eye Res (2003) 22(4):465-81. doi:10.1016/S1350-9462(03)00026-0

196. McKinnon SJ, Lehman DM, Kerrigan-Baumrind LA, Merges CA, Pease ME, Kerrigan DF, et al. Caspase activation and amyloid precursor protein cleavage in rat ocular hypertension. Invest Ophthalmol Vis Sci (2002) 43(4): 1077-87.

197. Oliver JE, Hattenhauer MG, Herman D, Hodge DO, Kennedy R, Fang-Yen $\mathrm{M}$, et al. Blindness and glaucoma: a comparison of patients progressing to blindness from glaucoma with patients maintaining vision. Am J Ophthalmol (2002) 133(6):764-72. doi:10.1016/\$0002-9394(02)01403-4

198. Jindal V. Interconnection between brain and retinal neurodegenerations. Mol Neurobiol (2015) 51(3):885-92. doi:10.1007/s12035-014-8733-6

199. Leske MC, Heijl A, Hussein M, Bengtsson B, Hyman L, Komaroff E, et al. Factors for glaucoma progression and the effect of treatment: the early 
manifest glaucoma trial. Arch Ophthalmol (2003) 121(1):48-56. doi:10.1001/ archopht.121.1.48

200. Shields MB. Normal-tension glaucoma: is it different from primary openangle glaucoma? Curr Opin Ophthalmol (2008) 19(2):85-8. doi:10.1097/ ICU.0b013e3282f3919b

201. Jain S, Aref AA. Senile dementia and glaucoma: evidence for a common link. JOphthalmic Vis Res (2015) 10(2):178-83. doi:10.4103/2008-322X. 163766

202. Sunderland T, Linker G, Mirza N, Putnam KT, Friedman DL, Kimmel LH, et al. Decreased beta-amyloid1-42 and increased tau levels in cerebrospinal fluid of patients with Alzheimer disease. JAMA (2003) 289(16):2094-103. doi:10.1001/jama.289.16.2094

203. Guo L, Salt TE, Luong V, Wood N, Cheung W, Maass A, et al. Targeting amyloid-beta in glaucoma treatment. Proc Natl Acad Sci U S A (2007) 104(33):13444-9. doi:10.1073/pnas.0703707104

204. Izzotti A, Bagnis A, Sacca SC. The role of oxidative stress in glaucoma. Mutat Res (2006) 612(2):105-14. doi:10.1016/j.mrrev.2005.11.001

205. Pinazo-Duran MD, Zanon-Moreno V, Gallego-Pinazo R, Garcia-Medina JJ. Oxidative stress and mitochondrial failure in the pathogenesis of glaucoma neurodegeneration. Prog Brain Res (2015) 220:127-53. doi:10.1016/bs.pbr. 2015.06.001

206. Trovato Salinaro A, Cornelius C, Koverech G, Koverech A, Scuto M, Lodato F, et al. Cellular stress response, redox status, and vitagenes in glaucoma: a systemic oxidant disorder linked to Alzheimer's disease. Front Pharmacol (2014) 5:129. doi:10.3389/fphar.2014.00129

207. Hou XR, Miao H, Tao Y, Li XX, Wong IY. Expression of cytokines on the iris of patients with neovascular glaucoma. Acta Ophthalmol (2015) 93(2):e100-4. doi:10.1111/aos.12510

208. Russo R, Varano GP, Adornetto A, Nucci C, Corasaniti MT, Bagetta G, et al. Retinal ganglion cell death in glaucoma: exploring the role of neuroinflammation. Eur J Pharmacol (2016) S0014-2999(16):30204-7. doi:10.1016/j. ejphar.2016.03.064

209. Cueva Vargas JL, Osswald IK, Unsain N, Aurousseau MR, Barker PA, Bowie D, et al. Soluble tumor necrosis factor alpha promotes retinal ganglion cell death in glaucoma via calcium-permeable AMPA receptor activation. J Neurosci (2015) 35(35):12088-102. doi:10.1523/JNEUROSCI. 1273-15.2015
210. Venkataraman ST, Flanagan JG, Hudson C. Vascular reactivity of optic nerve head and retinal blood vessels in glaucoma - a review. Microcirculation (2010) 17(7):568-81. doi:10.1111/j.1549-8719.2010.00045.x

211. Ding JD, Lin J, Mace BE, Herrmann R, Sullivan P, Bowes Rickman C. Targeting age-related macular degeneration with Alzheimer's disease based immunotherapies: anti-amyloid-beta antibody attenuates pathologies in an age-related macular degeneration mouse model. Vision Res (2008) 48(3):339-45. doi:10.1016/j.visres.2007.07.025

212. Hardy J, Selkoe DJ. The amyloid hypothesis of Alzheimer's disease: progress and problems on the road to therapeutics. Science (2002) 297(5580):353-6. doi:10.1126/science.1072994

213. Nicoll JA, Wilkinson D, Holmes C, Steart P, Markham H, Weller RO. Neuropathology of human Alzheimer disease after immunization with amyloid-beta peptide: a case report. Nat Med (2003) 9(4):448-52. doi:10.1038/ nm840

214. Volz C, Pauly D. Antibody therapies and their challenges in the treatment of age-related macular degeneration. Eur J Pharm Biopharm (2015) 95(Pt B):158-72. doi:10.1016/j.ejpb.2015.02.020

215. Andreasen N, Simeoni M, Ostlund H, Lisjo PI, Fladby T, Loercher AE, et al. First administration of the Fc-attenuated anti-beta amyloid antibody GSK933776 to patients with mild Alzheimer's disease: a randomized, placebo-controlled study. PLoS One (2015) 10(3):e0098153. doi:10.1371/journal pone. 0098153

Conflict of Interest Statement: The authors declare that the research was conducted in the absence of any commercial or financial relationships that could be construed as a potential conflict of interest.

The reviewer AM and handling editor declared their shared affiliation, and the handling editor states that the process nevertheless met the standards of a fair and objective review.

Copyright (๔) 2016 Masuzzo, Dinet, Cavanagh, Mascarelli and Krantic. This is an open-access article distributed under the terms of the Creative Commons Attribution License (CC BY). The use, distribution or reproduction in other forums is permitted, provided the original author(s) or licensor are credited and that the original publication in this journal is cited, in accordance with accepted academic practice. No use, distribution or reproduction is permitted which does not comply with these terms. 